\title{
Recombinant Probes Reveal Dynamic Localization of CaMKII $\alpha$ within Somata of Cortical Neurons
}

\author{
Rudy J. Mora, ${ }^{1}$ Richard W. Roberts, ${ }^{2}$ and Don B. Arnold ${ }^{1}$ \\ ${ }^{1}$ Department of Biology, ${ }^{2}$ Department of Chemistry, University of Southern California, Los Angeles, California 90089
}

In response to NMDA receptor stimulation, CaMKII $\alpha$ moves rapidly from a diffuse distribution within the shafts of neuronal dendrites to a clustered postsynaptic distribution. However, less is known about CaMKII $\alpha$ localization and trafficking within neuronal somata. Here we use a novel recombinant probe capable of labeling endogenous CaMKII $\alpha$ in living rat neurons to examine its localization and trafficking within the somata of cortical neurons. This probe, which was generated using an mRNA display selection, binds to endogenous CaMKII $\alpha$ at high affinity and specificity following expression in rat cortical neurons in culture. In $\sim 45 \%$ of quiescent cortical neurons, labeled clusters of CaMKII $\alpha$ 1-4 $\mu \mathrm{m}$ in diameter were present. Upon exposure to glutamate and glycine, CaMKII $\alpha$ clusters disappeared in $\mathrm{Ca}^{2+}$-dependent manner within seconds. Moreover, minutes after the removal of glutamate and glycine, the clusters returned to their original configuration. The clusters, which also appear in cortical neurons in sections taken from mouse brains, contain actin and disperse upon exposure to cytochalasin D, an actin depolymerizer. In conclusion, within the soma, CaMKII localizes and traffics in a manner that is distinct from its localization and trafficking within the dendrites.

\section{Introduction}

CaMKII $\alpha$ is a $\mathrm{Ca}^{2+}$-dependent seronine/threonine kinase that plays a critical role in synaptic plasticity (Soderling, 2000; Coultrap and Bayer, 2012; Lisman et al., 2012) and demonstrates remarkable trafficking behavior in response to increases in cytosolic $\mathrm{Ca}^{2+}$. GFP-tagged CaMKII $\alpha$ translocates rapidly and reversibly to postsynaptic sites within dendritic spines upon robust activation of NMDA receptors with glutamate and glycine (Shen and Meyer, 1999; Shen et al., 2000; Rose et al., 2009). Moderate NMDA receptor activation causes GFP-CaMKII $\alpha$ to cluster at gephyrin-positive inhibitory synaptic sites along the dendrites (Marsden et al., 2010). In addition to its distinct trafficking at postsynaptic sites, CaMKII also traffics to presynaptic sites upon activation with $\mathrm{Ca}^{2+}$ from intracellular stores in Drosophila (Shakiryanova et al., 2011).

Information about the trafficking of CaMKII $\alpha$ has come from experiments where the movements of exogenously expressed, GFP-tagged proteins were visualized (Shen and Meyer, 1999). Although GFP tagging enables proteins to be visualized in living cells (Marshall et al., 1995), many overexpressed proteins do not localize or traffic in the same manner as their endogenous counterparts, and can cause gain-of-function phenotypes (ElHusseini et al., 2000; Lardi-Studler et al., 2007). Recently, we have

Received May 16, 2013; revised Aug. 4, 2013; accepted Aug. 6, 2013.

Author contributions: R.M. and D.B.A. designed research; R.M. performed research; R.W.R. contributed unpublished reagents/analytic tools; R.M. analyzed data; R.M. and D.B.A. wrote the paper.

This work was supported by National Institutes of Health Grants NS041963 and MH086381 (D.B.A.), and Grants GM083898, GM060416, and OD006117 (R.W.R.). We thank Garrett Gross, Jason Junge, Terry Takahashi, and C. Anders Olson for helpful discussions about mRNA display; Samantha Ancona for help analyzing data; and Liana Asatryan in the University of Southern California Lentivirus Core Facility.

The authors declare no competing financial interests.

Correspondence should be addressed to Don B. Arnold at the above address. E-mail: darnold@usc.edu.

DOI:10.1523/JNEUROSCI.2108-13.2013

Copyright $\odot 2013$ the authors $\quad 0270-6474 / 13 / 3314579-12 \$ 15.00 / 0$ developed an alternative approach to visualizing proteins in living cells that avoids these drawbacks. cDNAs encoding antibody-like proteins, known as FingRs (Fibronectin intrabodies generated with mRNA display; Gross et al., 2013) are transfected into cells, which produce GFP-tagged FingRs that bind specifically to endogenous proteins, allowing them to be visualized. Probes that bind target molecules with high affinity and specificity are selected from a large library of mRNA-protein fusions encoding a scaffold based on the 10th type III fibronectin domain from human fibronectin with random amino acid substitutions (Roberts and Szostak, 1997; Koide et al., 1998; Takahashi et al., 2003; Olson and Roberts, 2007). Subsequently, an intracellular localization assay is used to select for FingRs that fold correctly and work well in the reduced environment of the cytoplasm. We have shown that these probes label the postsynaptic markers gephyrin and PSD95 in living cells in an accurate manner without perturbing neuronal function (Gross et al., 2013).

We generated a FingR that accurately labels endogenous CaMKII $\alpha$ and allows visualization of its localization and trafficking in living neurons. We found that endogenous CaMKII $\alpha$ localized and trafficked within dendrites in a manner very similar to that found in previous experiments with exogenous, tagged CaMKII $\alpha$. In contrast, within the soma, CaMKII $\alpha$ labeling revealed large, stable clusters $1-4 \mu \mathrm{m}$ in diameter in $\sim 45 \%$ of cortical neurons. These CaMKII $\alpha$ clusters rapidly and reversibly dispersed in a $\mathrm{Ca}^{2+}$-dependent manner within seconds after stimulation with glutamate and glycine. Withdrawal of glutamate caused the clusters to reappear in exactly the same locations and with exactly the same configurations as before stimulation. Thus, our CaMKII $\alpha$-FingR probe demonstrates that CaMKII $\alpha$ trafficking behavior in the cell body is dramatically different from its behavior in the dendrites, possibly reflecting distinct roles in the two compartments. 


\begin{tabular}{|c|c|}
\hline & $\mathrm{BC}$ \\
\hline 1 & MLEVKEASPTSIQISWIHHAKEIRYYRITYGETGGNSPVQGFTVPGSKSTATISGLKPGVDYTITVYAVTTVSEAWKRVLPIS INYRT \\
\hline 10 & MLEVKEASPTSIQISWIHHAKEIRYYRITYGETGGNSPVQGFTVPGSKSTATISGLKPGVDYTITVYAVTTVSFAWKRVLPIS INYRT \\
\hline 3 & MLEVKEASPTSIQISWVVNRKQVRYYRITYGETGGNSPVQEFTVPGSKSTATISGLKPGVDYTITVYAVTLMRFAWDHHLPIS INYRT \\
\hline 5 & MLEVKEASPTSIQISWHTKQLHIRYYRITYGETGGNSPVQEFTVPGSKSTATISGLKPGVDYTITVYAVTRTRSTFSWWPPISINYRT \\
\hline 13 & MLEVKEASPTSIQISWMSLRRQIRYYRITYGETGGNSPVQEFTVPGSKSTATISGLKPGVDYTITVYAVTRTRSTFSWWPPIS INYRT \\
\hline 6 & MLEVKEASPTSIQISWHTKQLHIRYYRITYGETGGNSPVQEFAVPGSKSTATISGLKPGVDYTITVYAVTRNRIMGLSKNPIS INYRT \\
\hline 15 & MLEVKEASPTSIQISWI HHAKEIRYYRITYGETGGNSPVQEFTVPGSKSTATISGLKPGVDYTITVYAVTRNRIMGLSKNPIS INYRT \\
\hline 19 & MLEVKEASPTSIQISWSPPQHAVRYYRITYGETGGNSPVQEFTVPGSKSTATISGLKPGVDYTITVYAVTRYPLPLKLFTPISINYRT \\
\hline 14 & MLEVKEASPTSIQISWMSLRRQIRYYRITYGETGGNSPVQEFTVPGSKSTATISGLKPGVDYTITVYVVTWKTMSNRFIKPI \\
\hline 17 & MLEVKEASPTSIQISWHPCDCRIRYYRITYGETGGNSPVQEFTVPGSKSTATISGLKPGVDYTITVYAVTPRLMKKRITSPISINYRT \\
\hline 20 & MLEVKEASPTSIQISWRYTRNATRYYRITYGETGGNSPVQEFTVPGSKSTATISGLKPGVDYTITVYAVTPRLMKKRITSPIS INYRT \\
\hline 16 & MLEVKEASPTSIQISWRYTVDPLRYYRITYGETGGNSPVQEFTVPGSKSTATISGLKPGVDYTITVYAVTPRLMKKRITSPISINYRT \\
\hline 2 & MLEVKEASPTSIQISWRYTVDPLRYYRITYGETGGNSPVQEFTVPGSKSTATISGLKPGVDYTITVYAVTPRLMKKRITSPIS INYRT \\
\hline 7 & MLEVKEASPTSIQISWRYTVDPLRYYRITYGETGGNSPVQEFTVPGSKSTATISGLKPGVDYTITVYAVTPRLMKKRITSPIS INYRT \\
\hline 8 & MLEVKEASPTGIQISWRYTVDPLRYYRITYGETGGNSPVQEFTVPGSKSTATISGLKPGVDYTITVYAVTPRLMKKRITSPISINYRT \\
\hline 18 & MLEVKEASPTSIQISWRYTVDPLRYYRITYGETGGNSPVQEFTVPGSKSTATISGLKPGVDYTITVYAVTPRLMKKRITSPIS \\
\hline
\end{tabular}

\section{Materials and Methods}

Target protein induction/purification/biotinylation. DNA encoding the rat CaMKII $\alpha$ C-terminal association domain (amino acids 336-478) was inserted into the pET28 plasmid (Novagen) downstream of a biotin acceptor peptide (AviTag, Avidity) and a 6X-His tag was transformed into BL21 (DE3) pLysS Escherichia coli (Stratagene). A transformed colony was inoculated into $2 \mathrm{ml}$ of LB overnight and $1.5 \mathrm{ml}$ of the overnight culture was grown in $2 \mathrm{~L}$ of broth at $37^{\circ} \mathrm{C}$ until $\mathrm{OD}_{600}=0.8$. AviTag6 XHis-CaMKII $\alpha$ protein expression was induced with $0.4 \mathrm{~mm}$ isopropyl $\beta$-D-thiogalactoside for $3 \mathrm{~h}$. The cells were centrifuged and the cell pellets were frozen at $-20^{\circ} \mathrm{C}$ overnight. The following day, the cell pellets were resuspended in $100 \mathrm{ml}$ of ice-cold Buffer A (20 mM Tris, pH 8.0, $100 \mathrm{~mm}$ $\mathrm{NaCl}, 5 \mathrm{~mm} \beta$-mercaptoethanol) plus $1 \mu \mathrm{g} / \mathrm{ml}$ aprotinin plus $2 \mu \mathrm{g} / \mathrm{ml}$ leupeptin plus $2 \mu \mathrm{M}$ sodium orthovanadate plus $2 \mathrm{~mm}$ PMSF plus 50 $\mu \mathrm{g} / \mathrm{ml}$ DNase. The resuspended cells were sonicated and centrifuged at $6000 \mathrm{rpm}$ for $15 \mathrm{~min}$ to pellet insoluble material. The soluble lysate was loaded onto a HisPur Cobalt resin column (Pierce) equilibrated with Buffer A and washed in Buffer B (20 mm Tris, pH 8.0, $100 \mathrm{~mm} \mathrm{NaCl}, 5 \mathrm{~mm}$ $\beta$-mercaptoethanol, $20 \mathrm{~mm}$ imidazole) using a BioLogic DuoFlow system (Bio-Rad). The protein was eluted from the column by a gradient of increasing imidazole concentration with Buffer C (20 mм Tris, $\mathrm{pH} 8.0$, $100 \mathrm{~mm} \mathrm{NaCl}, 5 \mathrm{~mm} \beta$-mercaptoethanol, $500 \mathrm{~mm}$ imidazole). Fractions containing protein were combined and then concentrated and exchanged into biotin ligation buffer (20 mu Tris, pH 8.0, $25 \mathrm{~mm} \mathrm{NaCl}, 2.5$ mм $\beta$-mercaptoethanol) using a Centricon-10 filter (Amicon). An in vitro biotin ligase reaction was performed to covalently link biotin to the acceptor peptide with BirA (Avidity) according to the manufacturer's instructions. Size exclusion chromatography was performed with a Superdex 200 column (GE Healthcare) equilibrated with storage buffer (20 mM Tris, $\mathrm{pH} 8.0,100 \mathrm{~mm} \mathrm{NaCl}, 5 \mathrm{~mm}$ DTT) to purify the protein and confirm the tetradecameric state of the complex. Fractions containing biotin-AviTag-6XHis-CaMKII $\alpha$ oligomer were combined and concentrated to $\sim 0.69 \mathrm{mg} / \mathrm{ml}$. To confirm the protein was biotinylated, a sample was incubated with streptavidin-conjugated agarose (Pierce) in a pull-down assay. The purified protein was aliquoted and stored at $-20^{\circ} \mathrm{C}$.

$m R N A$ display selection. Selection of CaMKII $\alpha$-specific fibronectin binders was performed according to an established protocol (Olson et al., 2008) with slight modification. In the first round of selection, PCR amplification was performed on a library consisting of $\sim 10^{12}$ molecules of the human fibronectin 10th type III domain with residues in the BC (7 aa) and the FG (10 aa) loops randomized (Olson and Roberts, 2007). The DNA library was transcribed in vitro with T7 RNA polymerase to produce mRNA. A DNA oligonucleotide containing puromycin on its $3^{\prime}$ end ( $\mathrm{pF} 30 \mathrm{P}$, Oligo Synthesis Resource, Yale School of Medicine) was ligated to the $3^{\prime}$ end of the mRNA with T4 DNA ligase (New England Biolabs).
The puromycin-conjugated mRNA was purified with Urea PAGE (Owl Separation Systems) and electroeluted with an Elutrap (Schleicher \& Schuell BioScience). The library was then desalted with a Centrisep column (Princeton Separations). An in vitro translation reaction was performed in rabbit reticulocyte lysate (Promega) and fusion of puromycin-conjugated mRNA to library protein was facilitated by the addition of potassium and magnesium (Liu et al., 2000). The reaction was stored overnight at $-80^{\circ} \mathrm{C}$. The mRNA-protein fusion library was purified with oligo(dT) cellulose type 7 (GE Healthcare) at $4^{\circ} \mathrm{C}$ in oligo(dT) buffer (100 mm Tris, pH 8.0, $1 \mathrm{~m} \mathrm{NaCl,} \mathrm{0.2 \%} \mathrm{Triton} \mathrm{X-100),}$ eluted in distilled water at room temperature, desalted with a Centrisep column (Princeton Separations) and reverse transcribed with Superscript II (Invitrogen). The purified mRNA-protein fusion library was incubated with AviTag-6XHis-CaMKII $\alpha$ immobilized on Neutravidinconjugated acrylamide beads (Pierce) at $4^{\circ} \mathrm{C}$ with rotation for $1 \mathrm{~h}$ in selection buffer [20 mu Tris, pH 8.0, $150 \mathrm{~mm} \mathrm{NaCl}, 0.02 \%$ Tween 20, 1 mм DTT (Sigma-Aldrich), $0.5 \mathrm{mg} / \mathrm{ml}$ bovine serum albumin (SigmaAldrich), $0.1 \mathrm{mg} / \mathrm{ml}$ sheared salmon sperm DNA (Ambion), 10\% fetal bovine serum (Invitrogen), $2 \mu \mathrm{g} / \mathrm{ml}$ streptavidin (Pierce), and $0.1 \%$ saturated biotin (Sigma-Aldrich)]. After washing the beads 5 times with selection buffer, the bound fibronectins served as a template for PCR amplification. The amplified DNA was subjected to another round of selection. While in Rounds 1 and 2 the target protein was immobilized on Neutravidin acrylamide, in Rounds 3-8 the target was immobilized on streptavidin agarose. The selection took place at $4^{\circ} \mathrm{C}$ in Rounds $1-4$, room temperature in Rounds 5 and 6 , and $37^{\circ} \mathrm{C}$ in Rounds 7 and 8. In vitro binding of fibronectins isolated from Rounds $4-8$ was measured by scintillation counting of mRNA-fused fibronectins labeled with ${ }^{35} \mathrm{~S}$ methionine (MP Biomedical) that were oligo(dT) purified and incubated with bead-immobilized CaMKII $\alpha$ or beads alone (background) in selection buffer at $4^{\circ} \mathrm{C}$.

cDNA constructs. The genes encoding fibronectins selected from Round 6 of the CaMKII $\alpha$ selection were inserted upstream of eGFP in the plasmid pGW (CaMKII $\alpha$ FingR 6.X-GFP). GTS-SA-CaMKII $\alpha$ was constructed by inserting the Golgi-targeting sequence of the Uukuniemi virus G1 protein (amino acids 398-459; Andersson et al., 1997) upstream of the streptavidin gene, which was upstream of the rat CaMKII $\alpha$ association domain gene (amino acids 336-478). GFP-CaMKII $\alpha$ was constructed by inserting the eGFP gene upstream of the full-length rat CaMKII $\alpha$ gene. mKate2- $\beta$ actin was constructed by inserting the mKate 2 gene (Evrogen) upstream of the rat $\beta$ actin gene.

COS7 cell Golgi-localizing FingR screen. COS7 cells (ATCC) were cultured in DMEM (ATCC) supplemented with $10 \%$ fetal bovine serum (Invitrogen) and $25 \mu \mathrm{g} / \mathrm{ml}$ gentamicin (Invitrogen) in a $5 \% \mathrm{CO}_{2}$ incubator. COS7 cells were transfected via Effectene (Qiagen) with the Golgilocalized GTS-SA-CaMKII $\alpha$ construct and a construct encoding a single 
A

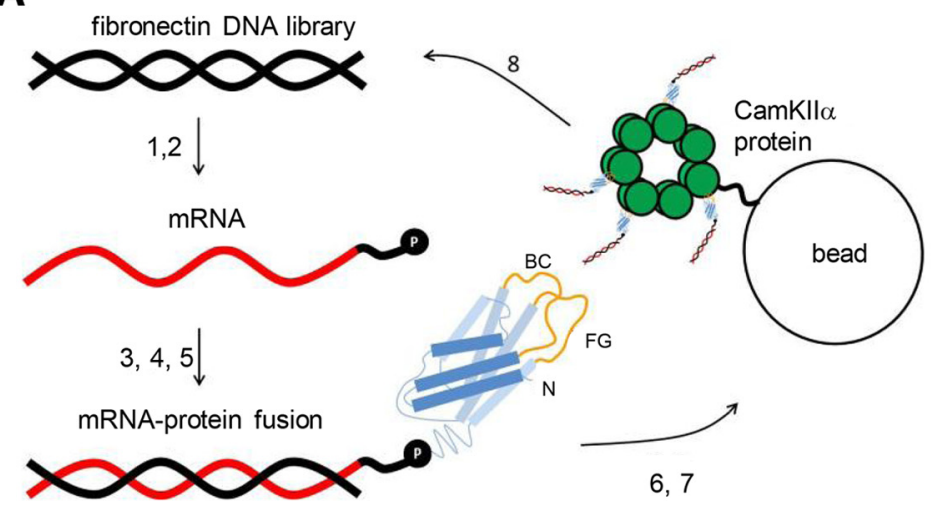

B

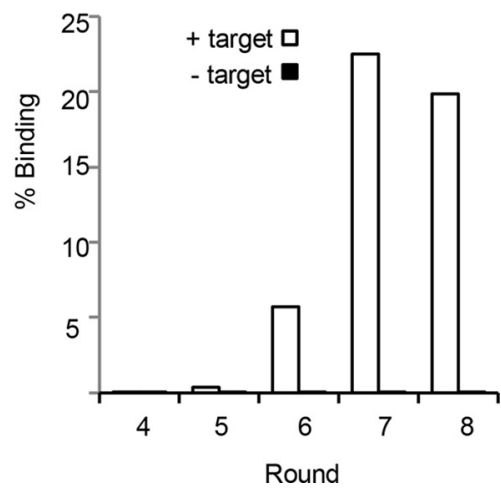

Figure 1. mRNA display selection on CaMKII $\alpha$ association domain. $A$, A round of selection consisting of (1) in vitro transcription of the fibronectin DNA library, (2) ligation of the resulting mRNA (red) to a DNA linker (black) fused to puromycin (P), (3) in vitro translation of mRNA and covalent linkage of fibronectin polypeptide (blue) to puromycin (randomized BC and FG loops in yellow), (4) oligo(dT) purification of mRNA-polypeptide fusions, (5) reverse transcription of mRNA to produce cDNA (black), (6) exposure of the mRNA/DNA-puromycin-polypeptide library to CaMKIl $\alpha$ association domain oligomers immobilized on agarose beads, (7) purification of mRNA/DNA-puromycin-polypeptides that bind at high affinity to CaMKIl $\alpha$ through affinity chromatography, and (8) PCR amplification of purified mRNA/DNA-puromycin-polypeptides to reconstitute a new DNA library of CaMKII $\alpha$-specific fibronectins. $\boldsymbol{B}$, Percentage of mRNA/DNA-puromycin-polypeptides in Rounds 4-7 that bind to either CaMKII $\alpha$ immobilized on agarose beads (+ target) or to beads alone ( - target) in a hot binding assay. The percentage binding to target increases with later rounds, with negligible nonspecific binding.

fibronectin isolated from Round 6 of the CaMKII $\alpha$ selection fused to eGFP (CaMKII $\alpha$ FingR 6.X-GFP). After $16 \mathrm{~h}$ of expression, the cells were fixed, permeabilized, and stained according to the immunocytochemistry protocol in this section. The 11 fibronectin proteins containing unique sequences isolated from Round 6 of the selection (Table 1) were screened for their ability to colocalize significantly with the Golgilocalized CaMKII $\alpha$ protein.

Dissociated cultures. Dissociated cultures were made as previously described (Lewis et al., 2009). All cells were transfected using CalPhos (Clontech) at 12-19 d in vitro (DIV) using the manufacturer's suggested protocol. Experimental protocols were conducted according to the $\mathrm{Na}$ tional Institutes of Health guidelines for animal research and were approved by the Institutional Animal Care and Use Committee at the University of Southern California.

Coimmunoprecipitation of CaMKII $\alpha$. A $100 \mathrm{~mm}$ dish containing rat dissociated cortical neurons, 12 DIV, was transduced with $4 \times 10^{5}$ infectious units of lentivirus encoding CaMKII $\alpha$ FingR-GFP and allowed to express for $5 \mathrm{~d}$. The lysate was centrifuged at $14,000 \mathrm{rpm}$ at $4^{\circ} \mathrm{C}$ for $15 \mathrm{~min}$ to remove insoluble material. The cells were then lysed in $1 \mathrm{ml}$ of ice-cold lysis buffer (150 mm NaCl, 1 mm EDTA, 10 mm Tris, pH 8.0, 1\% NP40, $0.12 \mathrm{mg} / \mathrm{ml}$ PMSF, $2 \mu \mathrm{g} / \mathrm{ml}$ leupeptin, $1 \mu \mathrm{g} / \mathrm{ml}$ aprotinin, $10 \mathrm{~mm} \mathrm{NaF}$, and $1 \mu \mathrm{g} / \mathrm{ml}$ pepstatin; all Sigma-Aldrich). The soluble lysate was cleared with protein A Sepharose beads (Pierce) for $1 \mathrm{~h}$ at $4^{\circ} \mathrm{C}$ with rotation. Ten microliters of anti-GFP agarose (MBL International) was added to the cleared lysate and incubated overnight at $4{ }^{\circ} \mathrm{C}$ with rotation. The following day, the agarose beads were separated from the lysate and washed three times with $500 \mu \mathrm{l}$ of wash buffer (same as lysis buffer but with $0.1 \%$ NP40). Five microliter samples of the original lysate (input), the antiGFP cleared lysate (flow through), and the anti-GFP agarose beads (immunoprecipitation) were separated by $12 \%$ SDS-PAGE and transferred to nitrocellulose membranes (Biorad). The blots were probed with mouse anti-CaMKII $\alpha$ (Thermo Fisher Scientific) at 1:2000, mouse antigephyrin (Synaptic Systems) at 1:1000, or mouse anti-GFP (Invitrogen) at 1:2000. Probes were detected with IRDye $800 \mathrm{CW}$ goat anti-mouse (LI-COR) or IRDye $680 \mathrm{CW}$ goat anti-mouse (LI-COR), both at $1: 10,000$. Images were captured with the Odyssey Infrared Imaging System (LI-COR).

Immunocytochemistry. Cells were fixed with $4 \%$ paraformaldehyde (Elecron Microscopy Sciences) in PBS for $5 \mathrm{~min}$ and washed three times with PBS for $5 \mathrm{~min}$ each. Cells were then permeabilized and blocked for $30 \mathrm{~min}$ in blocking solution (1\% bovine serum albumin (SigmaAldrich), 5\% normal goat serum (MP Biomedicals), and 0.1\% Triton X-100 (Sigma-Aldrich) in PBS. Primary antibodies were diluted in blocking solution and incubated with cells for $30 \mathrm{~min}$. Cells were washed three times with PBS for 5 min and then incubated with secondary antibodies diluted in blocking solution for $30 \mathrm{~min}$ in the dark. Cells were washed 3 times with PBS for 5 min and were mounted with Fluoromount-G (Elecron Microscopy Sciences). Primary antibodies used were chicken antiGFP (Aves Labs) at 1:1000, mouse anti-CaMKII $\alpha$ (Invitrogen) at 1:1000, and mouse anti-CaMKII $\beta$ (Invitrogen) at 1:2000. Secondary antibodies used were goat anti-chicken Alexa Fluor 488 (Invitrogen) at 1:1000, goat anti-mouse Alex Fluor 488 (Invitrogen) at 1:1000, goat anti-mouse $\mathrm{IgG}_{2 \mathrm{~b}} \kappa 488$ (Invitrogen) at 1:1000, goat anti-mouse Alex Fluor 594 (Invitrogen) at 1:1000, goat anti-mouse $\operatorname{IgG}_{2 \mathrm{a}}$ Alex Fluor 647 (Invitrogen) at 1:1000, phalloidin-Alexa Fluor 594 (Invitrogen) at $13.2 \mathrm{~nm}$, and biotinrhodamine (American Qualex) at 1:1000. Cells were imaged on a MRC1024 confocal microscope (Biorad) or an IX-81 inverted fluorescence microscope (Olympus).

CaMKII $\alpha$ cluster characterization/quantitation. Somatic CaMKII $\alpha$ clusters were defined as CaMKII $\alpha$-positive or CaMKII $\alpha$.FingR-GFPpositive spheroids in the cell body of neurons. Clusters were $1-4 \mu \mathrm{m}$ in diameter and had an average fluorescence intensity of $>20 \%$ of surrounding cell body regions. To quantitate the frequency of cluster occurrence in vitro, rat dissociated cortical neurons 12-13 DIV were transfected with either CaMKII $\alpha$.FingR-GFP, GFP alone, or GFPCaMKII $\alpha$. After $16 \mathrm{~h}$, expression cells were fixed, permeabilized, and stained for GFP and CaMKII $\alpha$ (see Immunocytochemistry). GFP-positive cells were imaged and analyzed for cluster occurrence $(n=60$ for CaMKII $\alpha$.FingR.GFP-expressing cells, $n=60$ for GFP-expressing cells, and $n=50$ for GFP-CaMKII $\alpha$-expressing cells). To quantitate the frequency of cluster occurrence in vivo, $5 \mu \mathrm{m}$-thick sections of postnatal day 90 adult mouse cortex were fixed, permeabilized, and stained for CaMKII $\alpha$ and DAPI (to identify nuclei and thus cell bodies). DAPIpositive cell bodies of CaMKII $\alpha$-positive cells were analyzed for cluster occurrence ( $n=190$ cells). Analysis was performed by a blind observer and significance of cluster occurrence between conditions was determined by Fisher's exact test. Images were taken on an IX-81 inverted fluorescence microscope (Olympus) and analyzed with ImageJ software (National Institutes of Health).

Live imaging. Rat dissociated cortical neurons made from brains from animals of both sexes were cultured on $35 \mathrm{~mm}$ Delta T dishes (Bioptechs) and transfected 12-19 DIV with CaMKII $\alpha$.FingR-GFP. After $16 \mathrm{~h}$, expression culture media was replaced with $10 \mathrm{~mm}$ HEPES plus $1 \times$ HBSS (Invitrogen) and imaged at $37^{\circ}$ on an IX-81 inverted fluorescence microscope (Olympus). Cells were stimulated with addition of $50 \mu \mathrm{m}$ glutamate plus $5 \mu \mathrm{M}$ glycine to the bath and images were captured every $0.5 \mathrm{~s}$ for 30-60 s during stimulation. In experiments exploring the $\mathrm{Ca}^{2+} \mathrm{de}-$ pendence of cluster disaggregation, cells were incubated first in $10 \mathrm{~mm}$ 
HEPES plus $1 \times$ HBSS plus 5 mm EGTA for 5 min before imaging. In experiments exploring the reaggregation of clusters, cells were stimulated with $50 \mu \mathrm{M}$ glutamate plus $5 \mu \mathrm{M}$ glycine for $75 \mathrm{~s}$ and the imaging buffer was replaced with $10 \mathrm{~mm}$ HEPES plus low-Ca ${ }^{2+} 1 \times$ HBSS $\left(0.1 \times \mathrm{Ca}^{2+}\right.$, i.e., $\left.0.126 \mathrm{~mm}\right)$ for $10 \mathrm{~min}$ before reimaging. In experiments exploring the effects of F-actin disruption on CaMKII $\alpha$ clusters, cells were imaged once before addition of $2 \mu \mathrm{M}$ cytochalasin D (Tocris Bioscience) or DMSO (vehicle) for $1.5-2 \mathrm{~h}$ incubation. Cells were then fixed, permeabilized, and stained for GFP and phalloidin-Alexa Fluor 594 before reimaging. In experiments exploring the localization of F-actin immediately after cluster disaggregation, neurons 12-14 DIV were cotransfected with CaMKII.FingR-GFP and mKate2- $\beta$ actin. After $16 \mathrm{~h}$, the cells were stimulated with glutamate/glycine and imaged as described above.

To plot the dynamics of CaMKII $\alpha$ cluster disaggregation in each neuron examined, a region of interest (ROI \#1) was drawn around a single CaMKII $\alpha$.FingR-GFP cluster using Image software. Another similarly shaped ROI was drawn in an adjacent ( $<1 \mu \mathrm{m}$ away) region of the cell body that contained no cluster (ROI \#2). The ratio of fluorescence intensity ( $\left.I_{\text {cluster/background }}\right)$ was plotted for each image captured every $0.5 \mathrm{~s}$ as a function of time following glutamate/glycine stimulation $(t=$ $0-21.5 \mathrm{~s}$ ). Each line in a plot indicates one cluster/noncluster ratio in a single neuron. In experiments where CaMKII $\alpha$.FingR-GFP was coexpressed with mKate2- $\beta$ actin, ROI \#1 indicates both the CaMKII $\alpha$ and actin cluster region while ROI \#2 indicate both the CaMKII $\alpha$ and actin adjacent noncluster region. In these experiments only two time points $(t=0 \mathrm{~s}$ and $t=21.5 \mathrm{~s}$ ) were plotted.

\section{Results}

Generation of a recombinant antibodylike protein that recognizes CaMKII $\alpha$

To visualize endogenous CaMKII $\alpha$ in living neurons, we generated a recombinant antibody-like protein, or FingR, that binds CaMKII $\alpha$ with high affinity and specificity and reports its localization and trafficking. We used mRNA display, an in vitro selection method capable of generating protein aptamers such that both the aptamer and the gene that encodes it are copurified (Roberts and Szostak, 1997). The selection was performed using a library of $10^{12}$ distinct mRNA-protein fusions composed of the 10th type III fibronectin (10FNIII) domain from human fibronectin with 17 aa residues randomized within the BC and FG loops (Fig. 1; Olson and Roberts, 2007). This scaffold has a $\beta$ sheet loop structure similar to that of the Fv region of antibodies, yet it has no disulfide bonds, making it stable even in reduced environments (Koide et al., 1998). As a target epitope, we chose the C-terminal association domain of CaMKII $\alpha$ (Hoelz et al., 2003; Rosenberg et al., 2006). We used the multimerized form of this do-
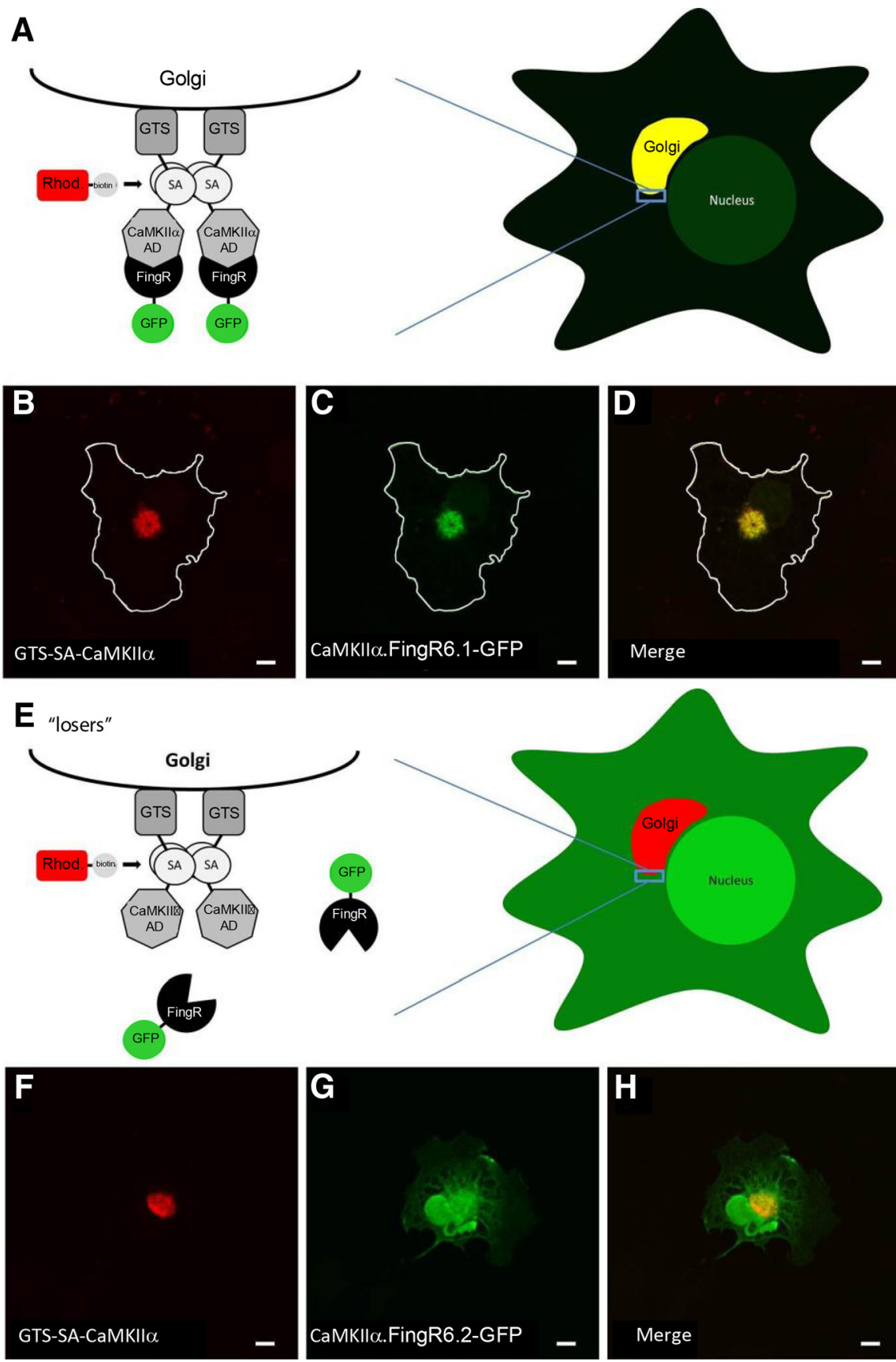

Figure 2. Intracellular Golgi localization assay for FingR/target binding. $A$, Schematic shows CaMKIl $\alpha$ target targeted to the surface of the Golgi through a Golgi targeting signal (GTS) following expression in COS-7 cells. Coexpressed FingRs that bind to the CaMKII $\alpha$ target are colocalized with the target at the Golgi. B, C, COS-7 cell coexpressing a Golgi-targeted CaMKII $\alpha$ association domain ( $\boldsymbol{B}$, GTS-SA-CaMKII $\alpha$, red) and a FingR that binds to CaMKII $\alpha$ (C, CaMKII $\alpha$.FingR6.1-GFP, green). D, Both GTS-SA-CaMKII $\alpha$ and CaMKII $\alpha$.FingR6.1-GFP colocalize at the Golgi. $\boldsymbol{E}$, Schematic of a FingR that does not bind to target following expression in COS-7 cells. F, GTS-SA-CaMKII $\alpha$ (red) targeted to the Golgi. G, CaMKIl $\alpha$. FingR6.2-GFP (green) is localized nonspecifically and does not colocalize with GTS-SA-CaMKII $\alpha$. H, Merged image shows that CaMKII $\alpha$.FingR6.2-GFP and GTS-SA-CaMKIl $\alpha$ do not overlap, indicating that the FingR does not bind at high affinity to the target. Scale bars, $5 \mu \mathrm{m}$.

main to select for proteins that bind to the exterior of the complex in a region with no known binding partners.

In each round of an mRNA display selection, single molecules consisting of 10FNIII polypeptide domains fused to the mRNA that encodes them are exposed to the target (Fig. 1A). The mRNA-protein fusions that bind to the target are purified using affinity chromatography and then amplified to reconstitute a library of molecules that preferentially bind to the target. To mon- 

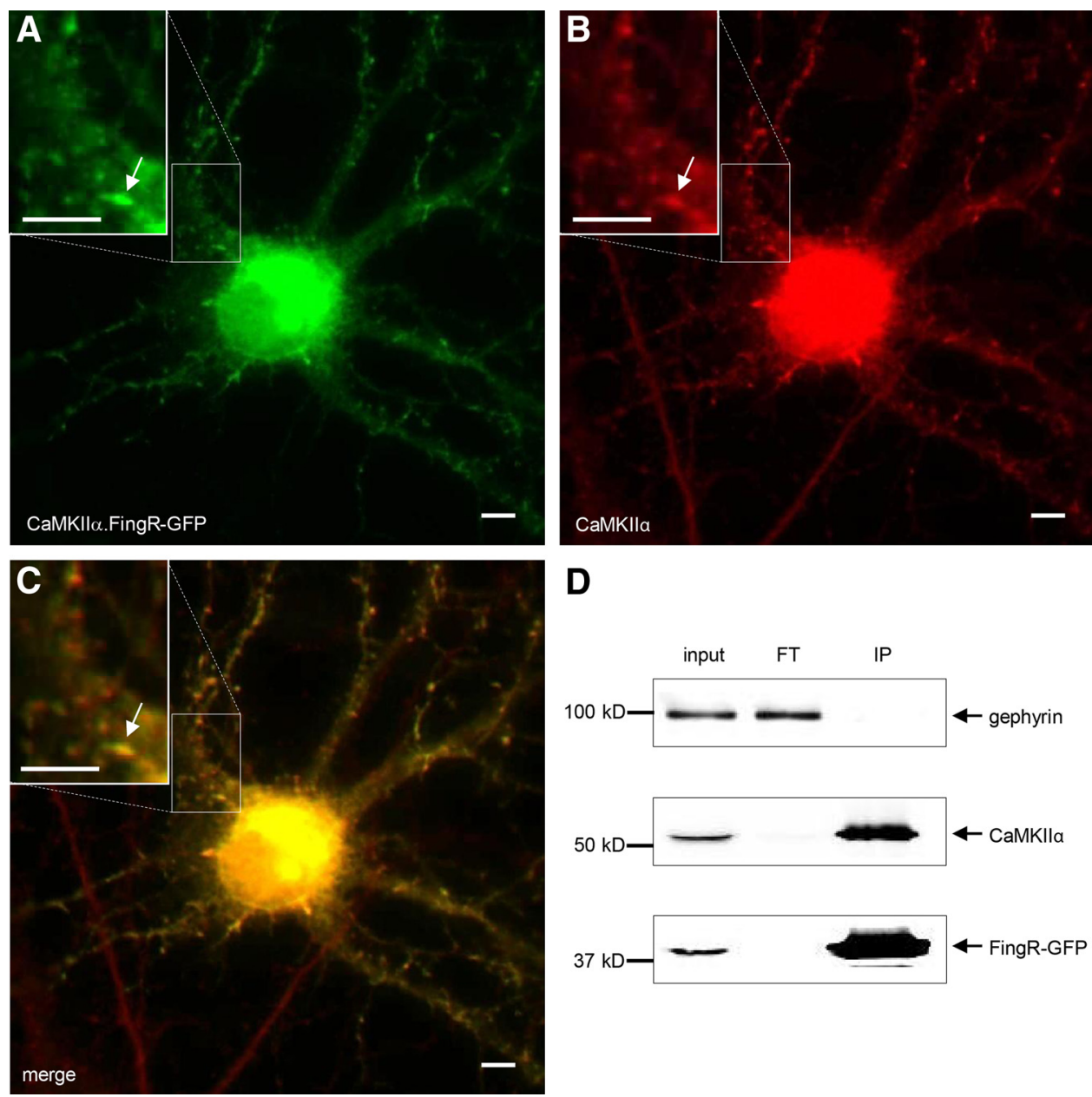

D
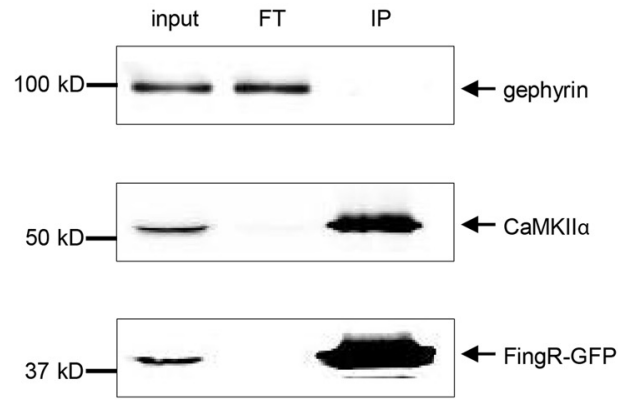

Figure 3. CaMKII $\alpha$.FingR-GFP colocalizes with endogenous CaMKIl $\alpha$ in neurons. $\boldsymbol{A}, \boldsymbol{B}$, CaMKIll $\alpha$.Fing R-GFP ( $\boldsymbol{A}$, green) expressed in a dissociated cortical neuron colocalizes similarly to CaMKIl $\alpha$ $(\boldsymbol{B}$, red). $\boldsymbol{C}$, Yellow color of merged image of CaMKII $\alpha$ and CaMKII $\alpha$.FingR-GFP indicates colocalization of the two proteins. D, Immunoprecipitation of CaMKIl $\alpha$.FingR-GFP expressed in cortical neurons in dissociated culture results in coprecipitation of virtually $100 \%$ of endogenous CaMKIl $\alpha$, indicated by its absence in flow through (FT). In contrast, endogenous gephyrin is not coprecipitated. Scale bars, $5 \mu \mathrm{m}$.
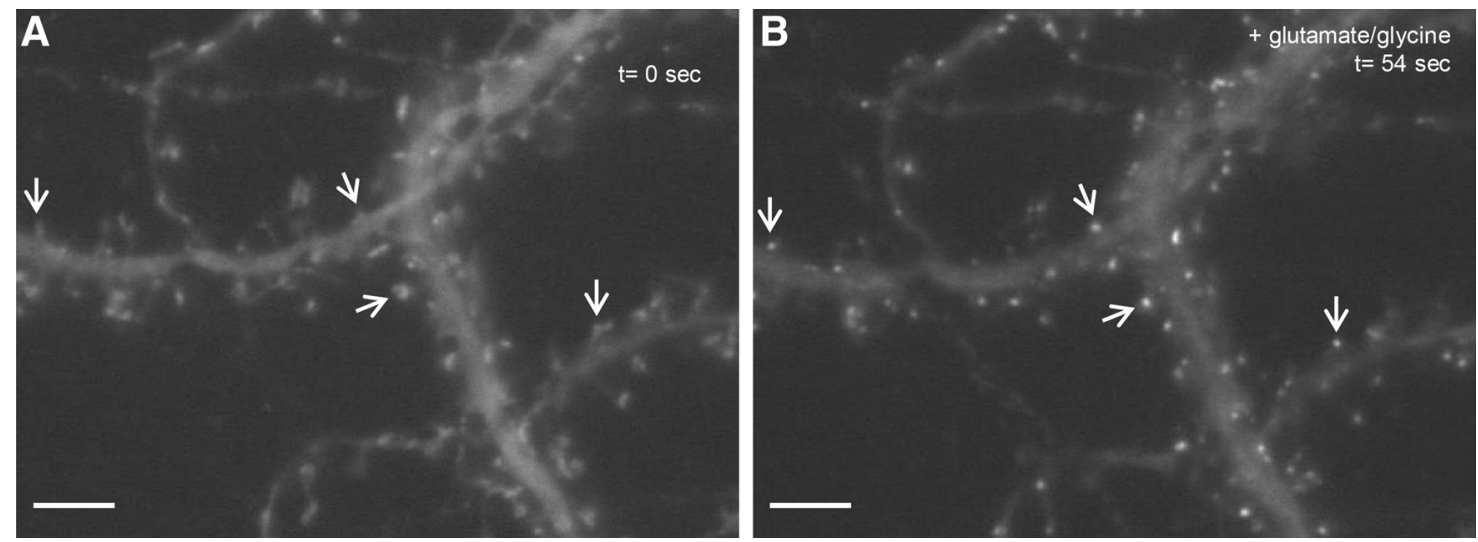

Figure 4. CaMKII $\alpha$.FingR-GFP translocates to dendritic spines upon excitatory stimulation. A, CaMKII $\alpha$.FingR-GFP expressed in cortical neurons in dissociated culture localizes in a diffuse fashion. $B, 54 \mathrm{~s}$ after addition of $50 \mu \mathrm{m}$ glutamate and $5 \mu \mathrm{m}$ glycine to the bath CaMKIl $\alpha$. FingR-GFP localizes specifically to puncta corresponding to the tips of dendritic spines. Scale bars, $5 \mu \mathrm{m}$.

itor the ability of library members to bind to the CaMKII $\alpha$ target, we performed a radioactive pull-down assay with the fibronectins isolated after Rounds 4-8. In Round 5, library members bound to target significantly above background. In Round 7, target binding peaked at $22.5 \%$ (Fig. $1 B$ ). Since the diversity of target-specific fibronectin sequences was likely large in the round just before peak binding, we amplified and sequenced members of the library from Round 6. Of the 13 clones sequenced, two were present in multiple copies, indicating that the selection was converging (Table 1 ). To test whether any of the 11 unique CaMKII $\alpha$ FingRs from this round bound to the target in a cytoplasmic environment, we engineered a GFP tag downstream of the gene encoding them and coexpressed the 

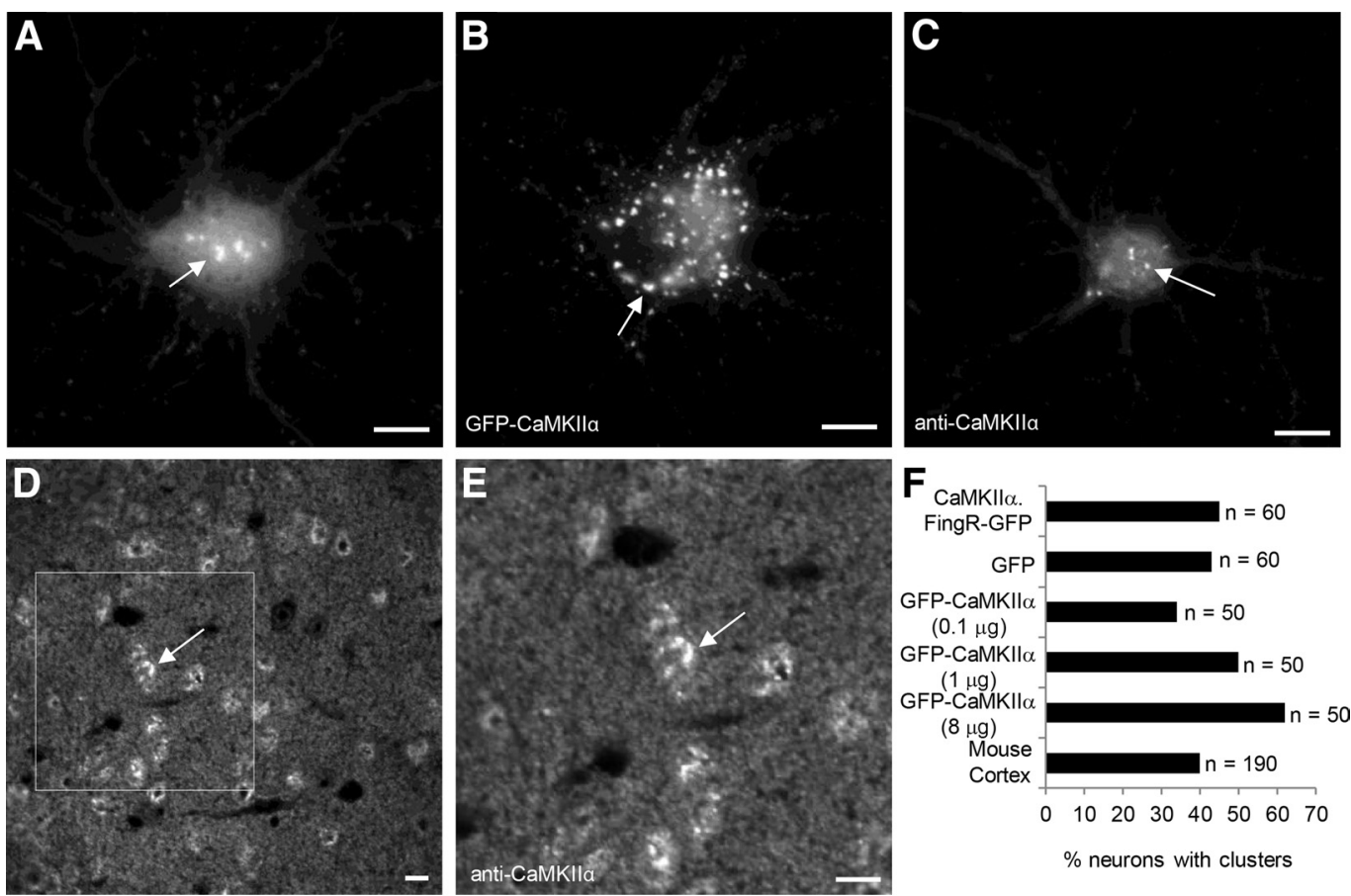

Figure 5. CaMKII $\alpha$ clusters in the cell bodies of cortical neurons in vitro and in vivo. A, CaMKIl $\alpha$.FingR-GFP localizes in clusters $\sim 1-4 \mu \mathrm{m}$ in diameter in the cell bodies of live cortical neurons. $B$, GFP-CaMKIl $\alpha$ also clusters in the cell body, but the number of clusters was larger and the intensity more variable than clusters of CaMKIl $\alpha$.FingR-GFP in live cortical neurons. C, Endogenous CaMKII $\alpha$, stained with an antibody is present in clusters in the cell bodies of fixed cortical neurons in culture. D, E, Sections of postnatal day (P) 90 mouse cortex stained with anti-CaMKIl $\alpha$ antibody show clusters within neuronal somata. $F$, Approximately $45 \%$ of cells in dissociated culture showed clusters of CaMKIl $\alpha$ when marked with CaMKIll $\alpha$.FingR-GFP or with anti-CaMKII $\alpha$ antibody staining. A similar percentage was found in sections cut from mouse cortex and stained with a CaMKIl $\alpha$ antibody. Although clusters were found in $\sim 35 \%$ of cells transfected with $0.1 \mu \mathrm{g}$ of CaMKII $\alpha$-GFP, increasing the amount of CaMKII $\alpha$-GFP caused an increase in the percentage of cells exhibiting clusters, suggesting that expression of the exogenous protein facilitated cluster formation. Approximately $40 \%$ of cells in cortices cut from P90 mouse cortex are positive for CaMKII $\alpha$ clusters. Scale bars, $10 \mu \mathrm{m}$.
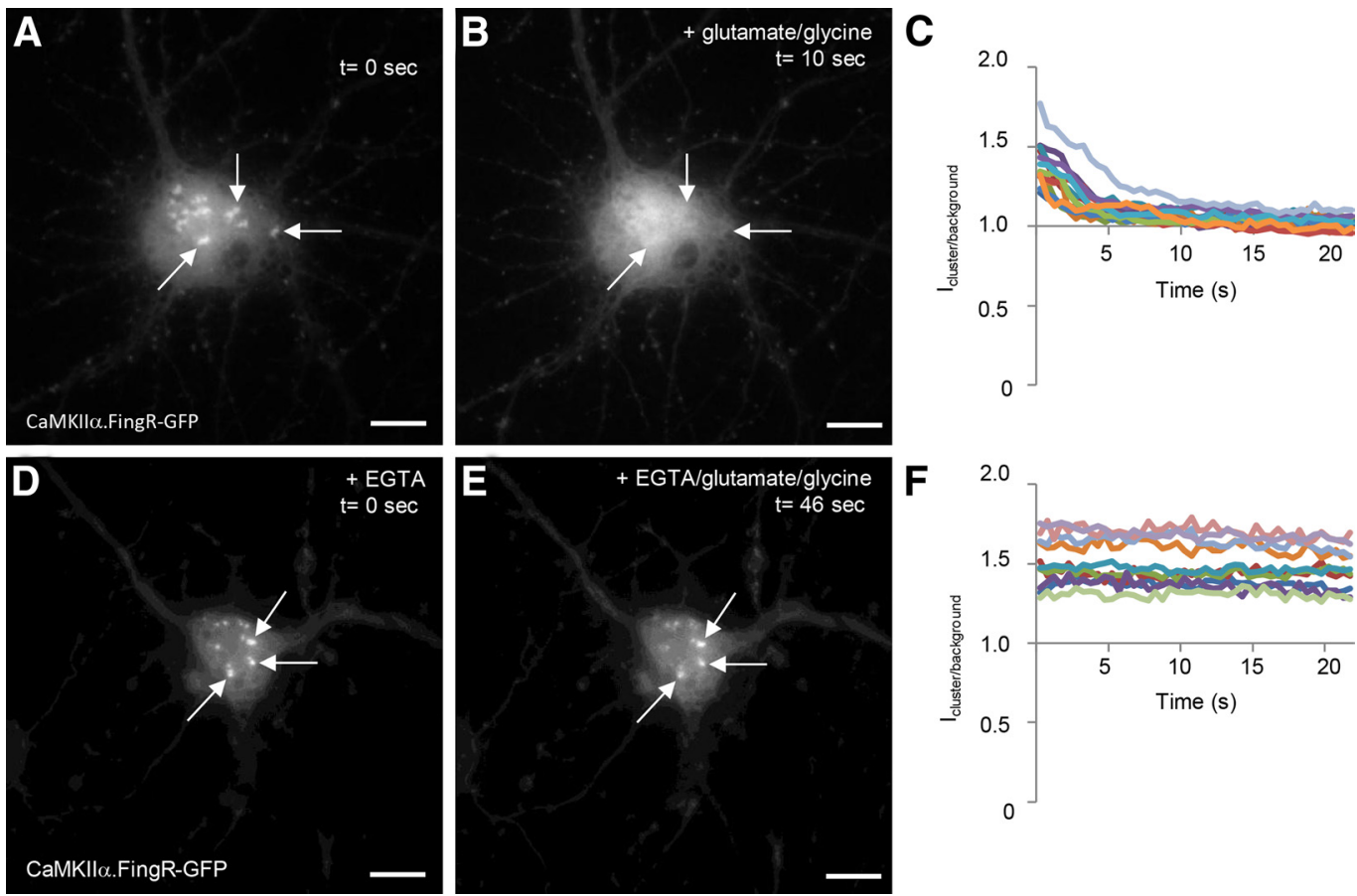

Figure 6. CaMKIl $\alpha$ clusters rapidly disperse upon exposure to high concentrations of $\mathrm{Ca}^{2+} \cdot \boldsymbol{A}, \mathrm{CaMKIl} \alpha$. FingR-GFP labels clusters in the cell bodies of cortical neurons in culture. $\boldsymbol{B}$, Ten seconds following the addition of $50 \mu \mathrm{m}$ glutamate and $5 \mu \mathrm{m}$ glycine, the clusters in $A$ have disappeared. $C$, Time courses of the ratio of fluorescence of CaMKIll $\alpha$.FingR-GFP at a point within a cluster versus at a point outside of the clusters (I duster/background $_{\text {f }}$ for 10 different cells show that the clusters disappear at similar rates following exposure of cells to $50 \mu \mathrm{m}$ glutamate and $5 \mu \mathrm{m}$ glycine. D, Clusters labeled by CaMKIll $\alpha$.FingR-GFP in cortical neurons in culture in the presence of $5 \mathrm{~mm}$ EGTA. E, Following exposure to $50 \mu \mathrm{m}$ glutamate and $5 \mu \mathrm{m}$ glycine for $46 \mathrm{sin}$ the presence of $5 \mathrm{~mm}$ EGTA, the clusters in $\boldsymbol{D}$ do not change in shape or intensity. F, Time courses of $I_{\text {duster/background }}$ for CaMKIl $\alpha$.FingR-GFP in 10 different cells shows that clusters do not disperse when exposed to $50 \mu \mathrm{m}$ glutamate and $5 \mu \mathrm{m}$ glycine in the presence of $5 \mathrm{~mm}$ EGTA. Scale bars, $10 \mu \mathrm{m}$. 

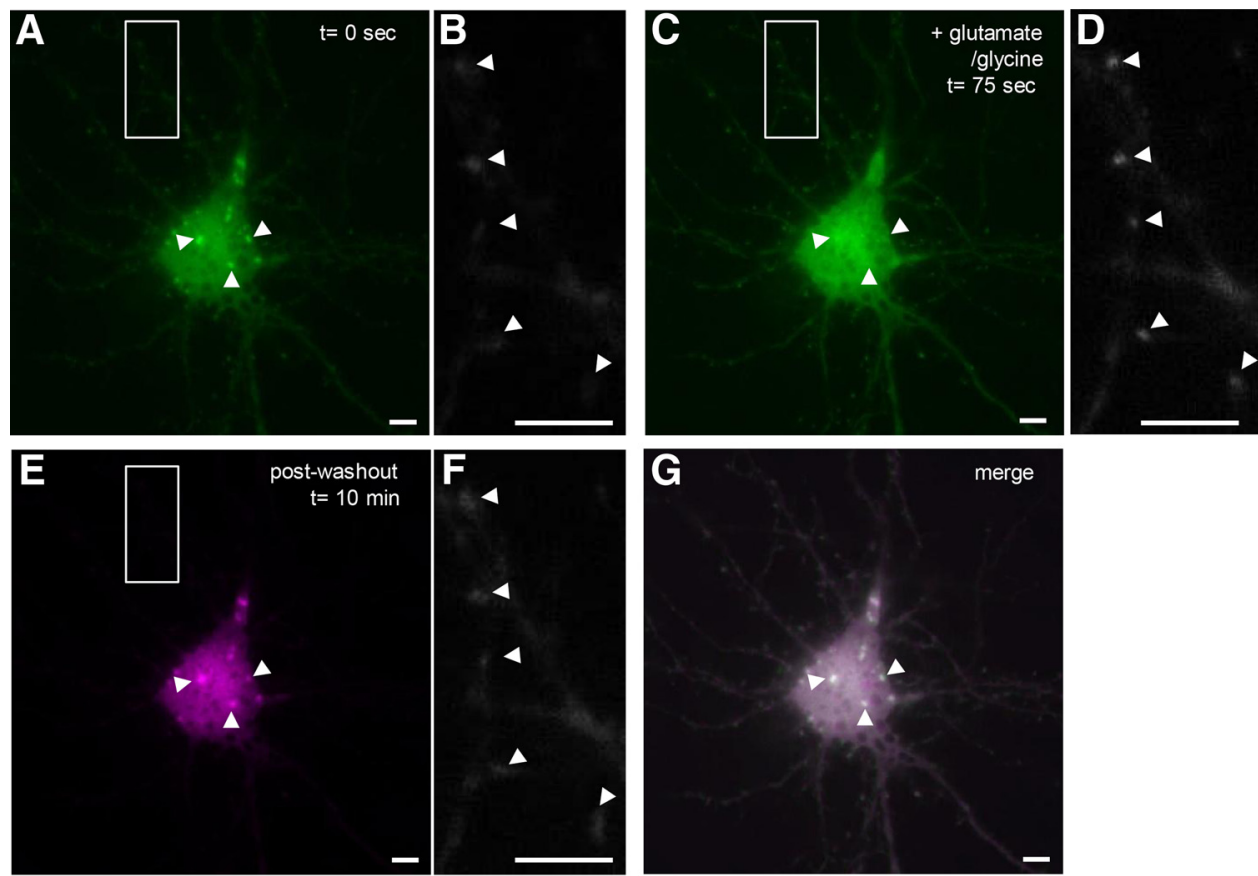

H

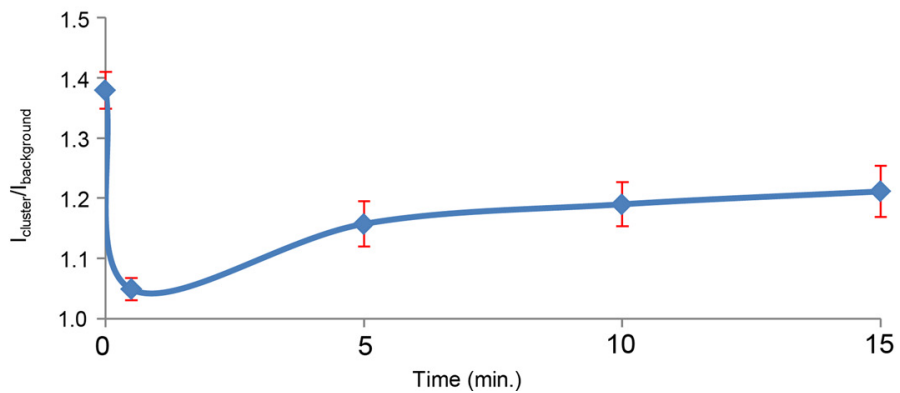

Figure 7. Following dispersal, clusters labeled with CaMKII $\alpha$.FingR-GFP re-form in their original positions and shapes. $A$, Clusters labeled with CaMKII $\alpha$.FingR-GFP in a cortical neuron in culture $\boldsymbol{B}$, Dendrite from the same neuron as in $\boldsymbol{A}$ shows faint, diffuse staining by CaMKII $\alpha$.FingR-GFP. C, Clusters in $\boldsymbol{A}$ dispersed following addition of $50 \mu \mathrm{m}$ glutamate and $5 \mu \mathrm{m}$ glycine. $\boldsymbol{D}$, CaMKII $\alpha$.FingRGFP labeled tight clusters in same dendrite as in $\boldsymbol{B}$ following addition of $50 \mu \mathrm{m}$ glutamate and $5 \mu \mathrm{m}$ glycine. $\boldsymbol{E}$, Following washout of glutamate and glycine and incubation for $10 \mathrm{~min}$, the clusters re-formed in their original positions and shapes. $\boldsymbol{F}$, Same dendrite as in $\boldsymbol{B}$ and $\boldsymbol{E}$ showed diffuse labeling by CaMKIll $\alpha$.FingR-GFP following washout of glutamate and glycine. $\boldsymbol{G}$, Superimposition of the images of clusters before and after dispersal and re-formation confirms that they re-formed in the same locations and configurations as the original clusters. $\boldsymbol{H}$, Time course of $I_{\text {cluster/background }}$ for CaMKIll $\alpha$.FingR-GFP in the presence ( $t=0$ to $t=75 \mathrm{~s}$ ) and absence $(t>75 \mathrm{~s})$ of glutamate and glycine. Error bars represent SEM. Scale bars, $10 \mu \mathrm{m}$.

resulting proteins (CaMKII $\alpha$.FingR.6.X-GFP) in COS cells coexpressing the target protein fused to a Golgi targeting sequence (GTS-SACaMKII $\alpha$; Fig. 2A; Andersson et al., 1997). Tight colocalization of CaMKII $\alpha$.FingR.6.1-GFP with GTS-SA-CaMKII $\alpha$ at the Golgi membrane revealed that the FingR bound to target with high affinity and specificity in the reducing environment of the cytoplasm (Fig. $2 B-D$ ). In contrast, another clone from Round 6, CaMKII $\alpha$.FingR.6.2-GFP, failed to colocalize significantly with target (Fig. $2 E-H$ ).

To determine whether CaMKII $\alpha$.FingR 6.1-GFP (henceforth referred to as CaMKII $\alpha$.FingR-GFP) binds to endogenous CaMKII $\alpha$, we expressed CaMKII $\alpha$.FingR-GFP in 12 DIV rat cortical neurons in dissociated culture. Following expression for $16 \mathrm{~h}$, the neurons were fixed and immunostained for endogenous CaMKII $\alpha$ so that its distribution could be compared with that of CaMKII $\alpha$.FingR-GFP. We found that CaMKII $\alpha$.FingR-GFP showed a striking overlap with endogenous CaMKII $\alpha$, which is consistent with the two proteins binding with high affinity (Fig. $3 A-C)$. To further test for interaction between CaMKII $\alpha$. FingRGFP and endogenous CaMKII $\alpha$, we assessed whether the FingR could coimmunoprecipitate endogenous CaMKII $\alpha$ following expression in cortical neurons. We infected dissociated neurons (12 $\mathrm{d}$ in culture) with a lentivirus encoding CaMKII $\alpha$.FingR-GFP and allowed it to express for $5 \mathrm{~d}$. Following cell lysis and probing of the lysate with anti-GFP conjugated beads, CaMKII $\alpha$.FingRGFP precipitated nearly all of the endogenous CaMKII $\alpha$ protein, whereas the unrelated protein gephyrin remained exclusively in the lysate (Fig. 3D). This result indicates CaMKII $\alpha$.FingR-GFP forms a complex with CaMKII $\alpha$ protein in a highly efficient manner. In addition, in a hot binding assay, $46 \%$ of CaMKII $\alpha$.FingRGFP bound to CaMKII $\alpha$, whereas only $3 \%$ bound to CaMKII $\beta$, indicating that binding to CaMKII $\alpha$ is highly specific (data not shown).

Previously, it has been shown that GFP-CaMKII $\alpha$ clusters specifically at postsynaptic excitatory sites in cultured neurons following stimulation of NMDA receptors by glutamate and glycine (Shen and Meyer, 1999; Shen et al., 2000; Rose et al., 2009). To determine whether CaMKII $\alpha$.FingR-GFP exhibits similar trafficking, we expressed it in 19 DIV cortical neurons in culture for $16 \mathrm{~h}$ and then exposed the cultures to $50 \mu \mathrm{M}$ glutamate and 5 $\mu \mathrm{M}$ glycine. Within $1 \mathrm{~min}$ after adding glutamate and glycine, CaMKII $\alpha$.FingR-GFP changed from being diffusely localized to forming puncta located on dendritic spines (Fig. 4). Thus, 
CaMKII $\alpha$.FingR-GFP appears to target to postsynaptic sites in the same manner as GFP-CaMKII $\alpha$ following stimulation with glutamate and glycine, suggesting that binding of CaMKII $\alpha$. FingR-GFP does not disrupt the localization or trafficking of endogenous CaMKII $\alpha$. These results also suggest that trafficking of CaMKII $\alpha$ in cortical neurons is similar to its trafficking in hippocampal neurons (Shen and Meyer, 1999).

\section{CaMKII $\alpha$ aggregates appear in neuronal somata}

Although the trafficking of CaMKII $\alpha$ in dendrites has been well characterized, much less is known about its trafficking within the soma. Following expression of CaMKII $\alpha$.FingR-GFP in cortical neurons in dissociated culture, we found that in many cells it had a somatic distribution that was distinctly different from its distribution within dendrites. CaMKII $\alpha$.FingRGFP was present in prominent clusters $\sim 1-4 \mu \mathrm{m}$ in diameter within the soma of $\sim 45 \%$ of living cells in culture $(n=60$ cells; Fig. 5A). To determine whether expression of CaMKII $\alpha$.FingR-GFP was responsible for the formation of the clusters, we examined staining of endogenous CaMKII $\alpha$ in cells expressing GFP alone (Fig. $5 C$ ). We found that the percentage of GFP-expressing cells containing CaMKII $\alpha$ clusters ( $43 \%$; Fig. 5F; $n=60$ cells) was not significantly different from that found in cells expressing CaMKII $\alpha$.FingR-GFP, indicating that expression of the FingR likely did not promote formation and/or retention of the clusters ( $p>0.99$, Fisher's exact test). Note that the appearance of clusters in live cells (Fig. $5 A$ ) and in fixed cells (Fig. 5C) was quite similar, suggesting that the clusters were not artifacts of fixation. In cells expressing GFP-CaMKII $\alpha$, the percentage of cells containing clusters within the cell body increased with increasing amounts of transfected DNA encoding GFPCaMKII $\alpha(34,50$, and $62 \%$ for $0.1,1$, and $8 \mu \mathrm{g}$, respectively; Fig. $5 B, F ; n=50$ cells each). Furthermore, increasing the amount of GFP-CaMKII $\alpha$ expressed in the cell significantly increases the number of clusters (7.01 \pm 1 clusters for $0.1 \mu \mathrm{g}$ of GFP-CaMKII $\alpha$ vs $16 \pm$ 4 clusters for $1 \mu \mathrm{g}$ of GFP-CaMKII $\alpha ; n=20, p<0.001, t$ test). These results indicate that GFP-CaMKII $\alpha$ expression influences CaMKII $\alpha$ cluster formation within the cell body, a significant drawback to using tagged, exogenous CaMKII $\alpha$ for studying endogenous CaMKII $\alpha$ clusters in somata. It should be noted, however, that it is possible that this clustering could be a result of GFP-GFP interactions, which might be reduced using a version of GFP that is less prone to multimerization (Bayer et al., 2006). To determine whether the presence of clusters was an artifact of dissociated culture, we examined the distribution of CaMKII $\alpha$ in fixed sections from adult mice immunostained with an anti-CaMKII $\alpha$ antibody (Fig. 5D,E). Approximately $40 \%$ of cortical neurons had clusters of CaMKII $\alpha$ in the somata ( $n=190$ cells), a number that is not statistically distinct from the percentage of neurons with similar clusters in culture (Fig. $5 F ; p>0.77$, Fisher's exact test). Thus, clusters appear in approximately the same proportion of cortical neurons, both in culture and in vivo, and their formation is not induced by expression of
CaMKII $\alpha$.FingR-GFP. Note that the difference in the appearance of clusters in intact tissue versus those in dissociated neurons could be due to actual differences in the clusters in the two different conditions or merely due to differences in fixation between dissociated cultures and intact brain sections.

\section{Dynamics of CaMKII $\alpha$ clusters}

To study the dynamics of clusters of CaMKII $\alpha$ in living neurons, we exposed dissociated cortical neurons to $50 \mu \mathrm{M}$ glutamate and $5 \mu \mathrm{M}$ glycine, which causes CaMKII $\alpha$ to cluster at postsynaptic sites. Strikingly, we found that within $10 \mathrm{~s}$ after addition of glutamate and glycine the clusters dispersed in $100 \%$ of cells (Fig. $6 A-C$ ). In particular, the ratio of the intensity of CaMKII $\alpha$.FingR-GFP inside a cluster, versus background intensity within the cell body was significantly higher than $1, I_{\text {cluster/background }}=1.39+/-0.04$ at $t=0$ $(n=13$ cells $)$, whereas $I_{\text {cluster/background }}=1.06+/-0.01$ at $t=10 \mathrm{~s}$, a significant difference $(p<0.0001$, Wilcoxon $)$. Because $\mathrm{Ca}^{2+}$ plays a prominent role in both the activation of CaMKII $\alpha$ and its aggregation at excitatory synaptic sites in dendrites (Shen and Meyer, 1999), we tested whether $\mathrm{Ca}^{2+}$ influx is necessary for the disaggregation of cell body clusters. To do so, we incubated the cells first in the $\mathrm{Ca}^{2+}$ chelator EGTA followed by addition of glutamate and glycine. Under these circumstances, there was no difference in the appearance of clusters before and after addition of glutamate and glycine (Fig. $6 D-F$ ). In addition, quantitation confirmed these qualitative results $\left[I_{\text {cluster/background }}=1.50 \pm 0.05\right.$ at $t=0 \mathrm{~s}(n=10)$, whereas $I_{\text {cluster/background }}=1.49 \pm 0.05$ at $t=10 \mathrm{~s}$, a difference that is not significant $(p>0.8$, Wilcoxon $)]$. Thus, $\mathrm{Ca}^{2+}$ influx is necessary for the disaggregation of CaMKII $\alpha$ clusters. We also tested whether CaMKII $\alpha$ clusters would reaggregate following dispersal if glutamate and glycine were removed from the bath 

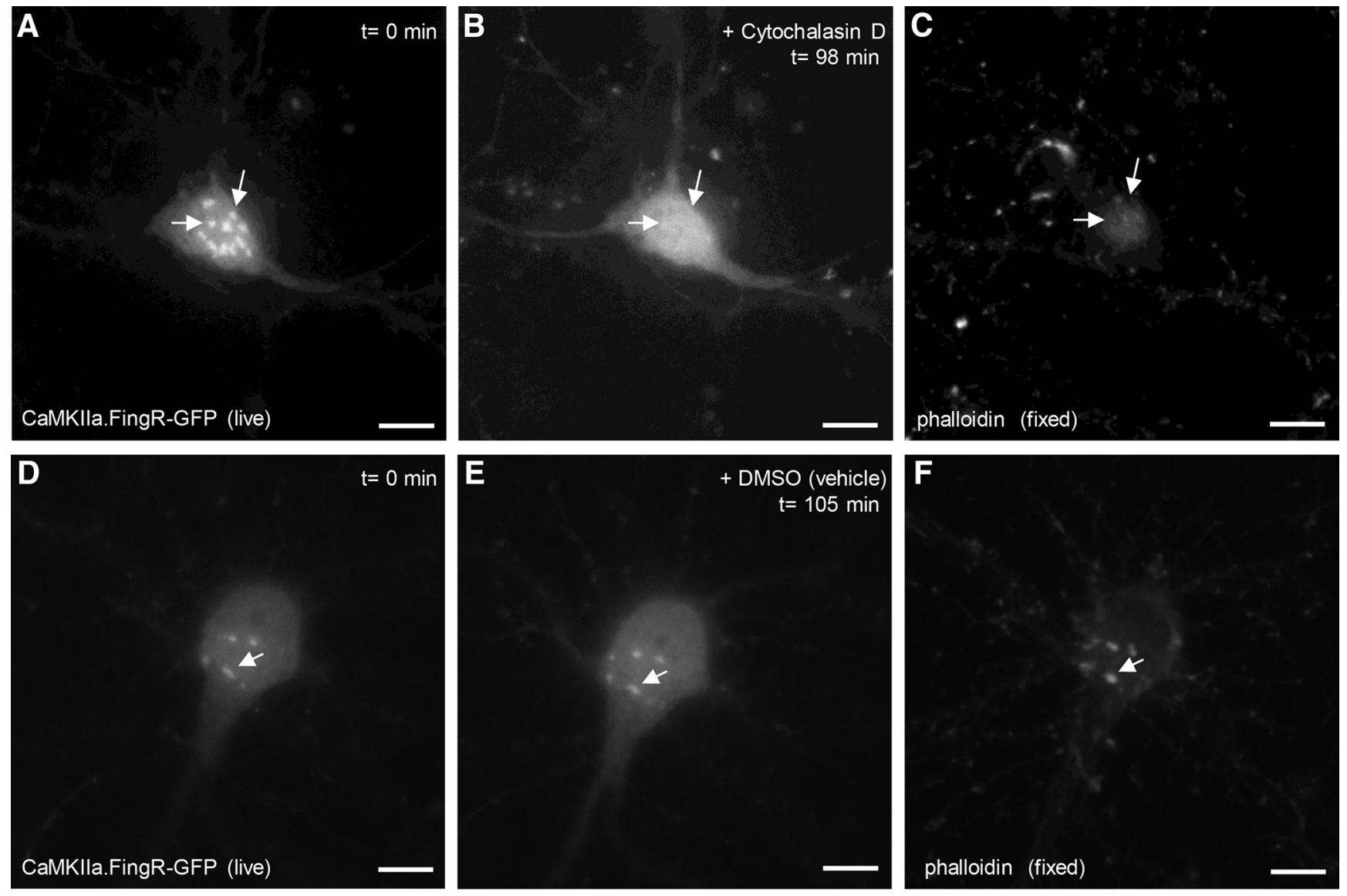

G

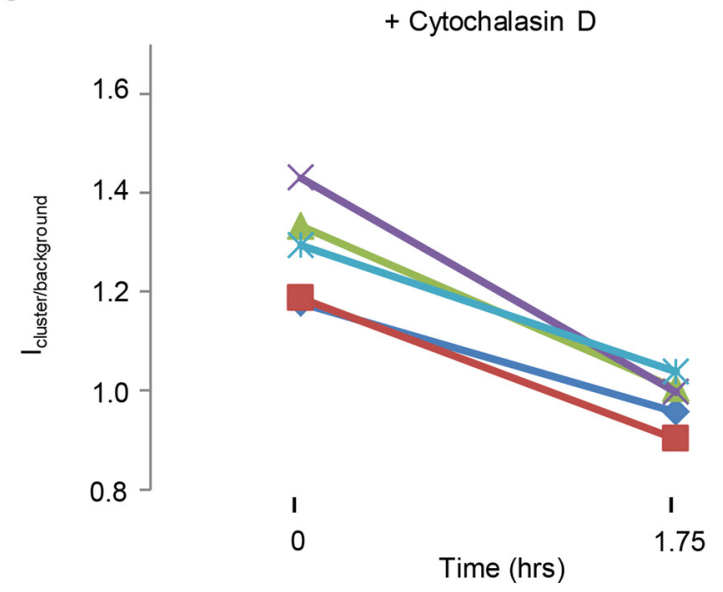

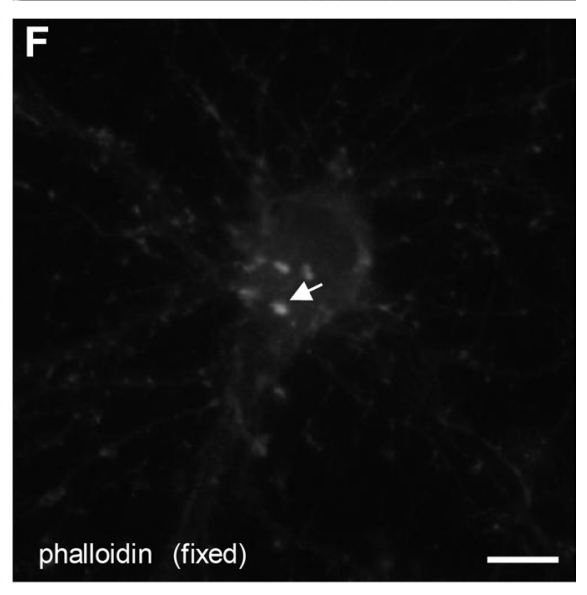

$+\mathrm{DMSO}$
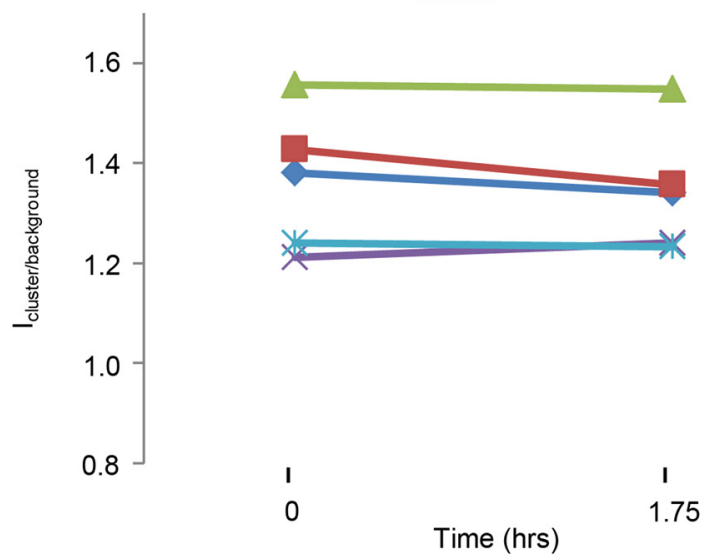

Figure 9. Cytochalasin D disruption of F-actin causes CaMKII clusters to disperse. $A$, CaMKIll $\alpha$.FingR-GFP-labeled clusters in cell body of a cortical neuron in culture. $B$, Addition of cytochalasin D $(2 \mu \mathrm{M})$ for 98 min results in dispersal of the clusters in $\boldsymbol{A}$. C, Phalloidin staining of cell in $\boldsymbol{B}$ and $\boldsymbol{C}$ verifies that addition of cytochalasin $D$ mediated dispersal of actin clusters. $\boldsymbol{D}-\boldsymbol{F}$, Clusters in a cortical pyramidal neuron labeled with CaMKII $\alpha$.FingR-GFP $(\boldsymbol{D})$ are not dispersed by DMSO $(\boldsymbol{E})$, which also leaves clusters of actin filaments intact $(\boldsymbol{F})$. $\mathbf{G}, I_{\text {cluster/background }}$ at $t=0 \mathrm{~s}$ and $t=21.5 \mathrm{~s}$ for CaMKII $\alpha$.FingR-GFP following addition of either cytochalasin D or DMSO. Scale bars, $10 \mu \mathrm{m}$.

and replaced with a low-Ca ${ }^{2+}$ buffer. The clusters reappeared in exactly the same places and with the same shapes as the originals, suggesting the existence of spatially fixed loci that could mediate reaggregation (Fig. $7 A, C, E, G$ ). Note that CaMKII $\alpha$ clusters in the dendrites went from diffuse, to clustered, and then to diffuse again during this time (Fig. $7 B, D, F$ ). A time course of the relative intensity of CaMKII $\alpha$ in clusters versus background CaMKII $\alpha$ ( $\left.I_{\text {cluster/background }}\right)$ confirms the qualitative results (Fig. $7 H$ ). In addition, $I_{\text {cluster/background }}$ at time points $0,0.5$, and $15 \min \left(I_{\text {cluster/background, } 0}=1.37 \pm 0.03 ; I_{\text {cluster/background, } 0.5}=\right.$ $\left.1.05 \pm 0.02 ; I_{\text {cluster/background, } 15}=1.21 \pm 0.04, n=5\right)$ are all significantly different from one another $(p<0.001$, ANOVA).

\section{CaMKII $\alpha$ clusters associate with F-actin}

Since our previous experiments suggest CaMKII $\alpha$ clusters associate with and dissociate from fixed structures within the soma, we tested whether they colocalize with actin, which has been shown to associate with CaMKII $\beta$ (Shen et al., 1998). Immunostaining of cultured cortical neurons with antibodies detecting CaMKII $\alpha$, CaMKII $\beta$, and phalloidin, a toxin that labels the 

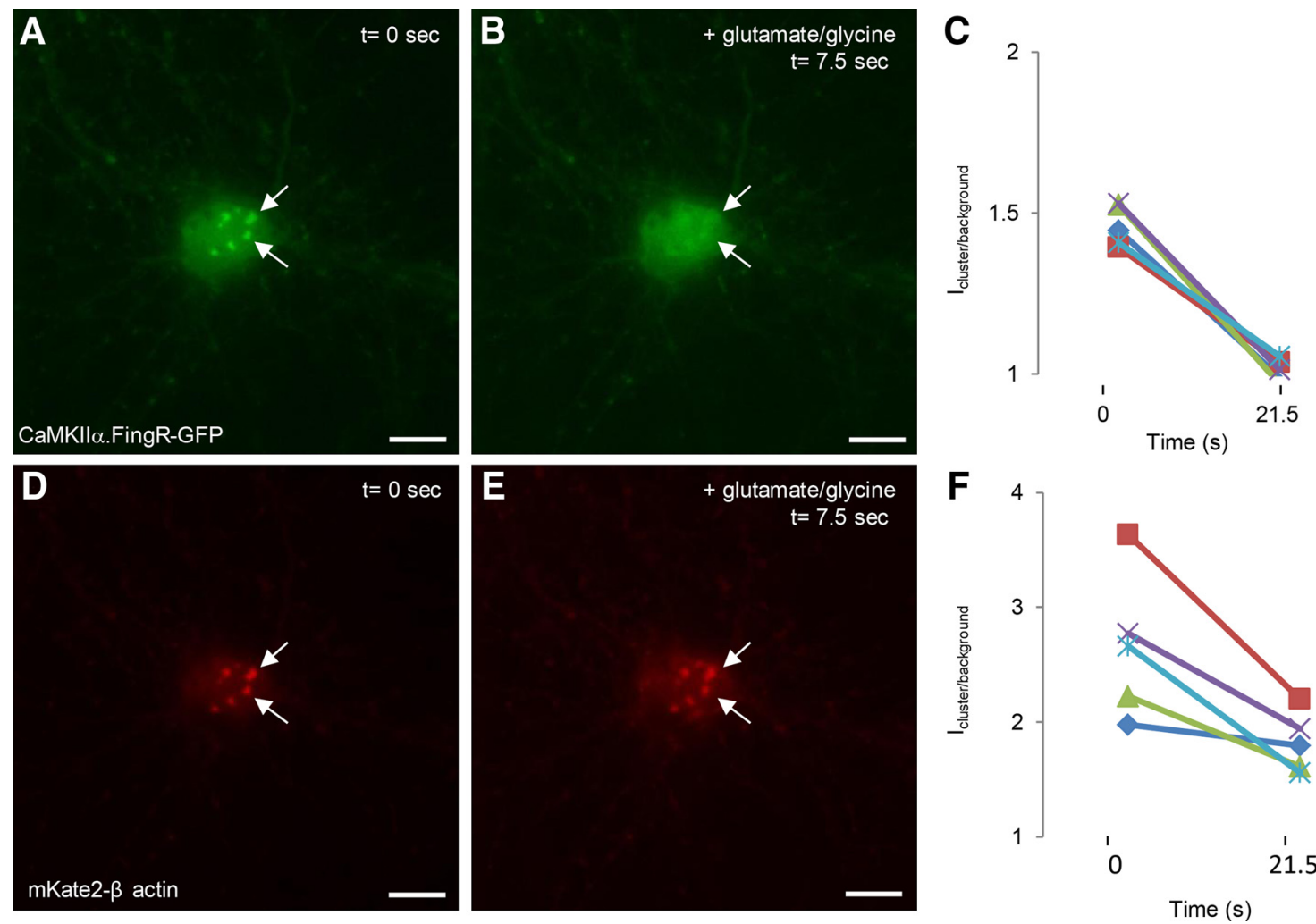

Figure 10. CaMKII $\alpha$ clusters dissociate from F-actin clusters upon stimulation. $A$, Clusters labeled with CaMKIl $\alpha$.FingR-GFP (green) in cortical neurons. B, Addition of $50 \mu \mathrm{m}$ glutamate and $5 \mu \mathrm{M}$ glycine for $7.5 \mathrm{~s}$ results in dispersal of the clusters. $C, I_{\text {duster/background }}$ for CaMKIl $\alpha$. FingR-GFP shows that the clusters have completely dispersed within $21.5 \mathrm{~s}$. $D$, Clusters of $\beta$ actin fused to mKate2 in the same cell as in $\boldsymbol{A}$. $\boldsymbol{E}$, Addition of $50 \mu \mathrm{m}$ glutamate and $5 \mu \mathrm{m}$ glycine for $7.5 \mathrm{~s}$ does not disperse the clusters. $\boldsymbol{F}$, Time course of $I_{\text {cluster/background }}$ for mKate2- $\beta$ actin during exposure to $50 \mu \mathrm{m}$ glutamate and $5 \mu \mathrm{m}$ glycine. Scale bars, $10 \mu \mathrm{m}$.

F-actin cytoskeleton, revealed that CaMKII $\alpha$ and phalloidin colocalized precisely in somatic clusters (Fig. $8 A, C, D$ ), suggesting the clusters of CaMKII $\alpha$ associate with F-actin structures. Although there was some overlap of phalloidin staining with CaMKII $\beta$, it was not as pronounced (Fig. $8 B-D$ ). To determine whether disruption of F-actin could disperse CaMKII $\alpha$ clusters, we imaged CaMKII $\alpha$.FingR-GFP-expressing cells before and after addition of cytochalasin $\mathrm{D}$, an inhibitor of actin polymerization, or DMSO (vehicle). Addition of cytochalasin D to the bath, which eliminated phalloidin staining (Fig. 9C), caused clusters of CaMKII $\alpha$.FingR-GFP to disperse [Fig. $9 A, B, G ; I_{\text {cluster/background }}=$ $1.28 \pm 0.04$ at $t=0 ; I_{\text {cluster/background }}=0.98 \pm 0.02$ at $t=1.75 \mathrm{~h}$; a significant difference $(p<0.01$, Wilcoxon $)]$. In contrast, DMSO had no effect on either phalloidin staining (Fig. $9 F$ ), or CaMKII $\alpha$.FingR-GFP clusters [Fig. 9D,E,G; $I_{\text {cluster/background }}=$ $1.36 \pm 0.06$ at $t=0, n=5$ cells; $I_{\text {cluster/background }}=1.34 \pm 0.06$ at $t=1.75 \mathrm{~h}$; a difference that is not significant $(p>0.8$, Wilcoxon)]. Thus, the presence of intact actin filaments is necessary for clustering of CaMKII $\alpha$.

To determine whether F-actin clusters disappear simultaneously with clusters of CaMKII $\alpha$.FingR-GFP upon stimulation of NMDA receptors, we coexpressed CaMKII $\alpha$.FingR-GFP along with the farred fluorescent protein mKate 2 fused to $\beta$-actin (mKate2- $\beta$ actin) in cultured neurons and stimulated the cells with glutamate and glycine. CaMKII $\alpha$.FingR-GFP and mKate2- $\beta$-actin colocalized precisely in soma clusters and CaMKII $\alpha$.FingR-GFP clusters dispersed rapidly $(<10 \mathrm{~s})$ upon addition of glutamate and glycine (Fig. $10 A-C)$. For CaMKII $\alpha$.FingR-GFP, $I_{\text {cluster } / \text { background }}=$ $1.46 \pm 0.03$ at $t=0(n=5$ cells $)$, whereas $I_{\text {cluster/background }}=1.01 \pm$ 0.02 at $t=20 \mathrm{~s}$, a difference that is significant ( $p<0.01$, Wilcoxon).
In contrast, mKate $2-\beta$-actin clusters were still clearly visible beyond $20 \mathrm{~s}$, a point at which all of the CaMKII $\alpha$.FingR-GFP clusters had completely dispersed (Fig. 10D-F). However, for mKate2- $\beta$-actin, $I_{\text {cluster/background }}=2.7 \pm 0.3$ at $t=0$ ( $n=5$ cells $)$, whereas $I_{\text {cluster/background }}=1.8 \pm 0.1$ at $t=20 \mathrm{~s}$, a difference that is still significant ( $p<0.02$, Wilcoxon). This result suggests that F-actin clusters remain in the cell body upon stimulation with glutamate and glycine, although the amount of F-actin within them is significantly reduced. Thus, our data are consistent with the idea that clusters of F-actin act as platforms that sequester CaMKII $\alpha$ within the soma under basal $\mathrm{Ca}^{2+}$ levels. Following a rise in $\mathrm{Ca}^{2+}$, CaMKII $\alpha$ clusters are rapidly dispersed, causing an abrupt increase in the concentration of free CaMKII $\alpha$ within the soma.

\section{Discussion}

CaMKII $\alpha$ clusters in synaptic sites in dendritic spines upon activation of NMDA receptors, a phenomenon that plays an important role in both the induction and maintenance of LTP and spatial learning (Sanhueza et al., 2011). In addition, CaMKII $\alpha$ clusters at nonsynaptic sites, including ones in the soma, under ischemic conditions of low pH (Aronowski et al., 1992), as well as following prolonged exposure to glutamate and glycine (Dosemeci et al., 2000; Hudmon et al., 2005; Vest et al., 2009). Here we describe a novel clustering behavior of CaMKII $\alpha$ that occurs exclusively in the cell bodies of almost half of cortical neurons both in culture and in vivo. Unlike the clustering of CaMKII $\alpha$ in dendrites, the clustering observed in this article occurs under resting, nonischemic conditions. Exposure of cells to glutamate and glycine leads to dispersal of clusters in $<10 \mathrm{~s}$ in a $\mathrm{Ca}^{2+}$-dependent manner. If glutamate and glycine are removed following dispersal 
of clusters, they re-form within 10 min in exactly the same configurations that they had been in before dispersal. Clusters of CaMKII $\alpha$ are colocalized with clusters of CaMKII $\beta$ and with F-actin. The fact that F-actin clusters do not disappear upon stimulation with glutamate and glycine suggests that F-actin might be part of a cytoskeletal structure that provides a platform for initial formation and re-formation of CaMKII $\alpha$ clusters.

The observations of CaMKII $\alpha$ clustering in this study were enabled by its labeling with a novel recombinant probe, CaMKII $\alpha$.FingR, that binds to CaMKII $\alpha$ with high affinity and specificity. CaMKII $\alpha$.FingR was selected from a library whose members consist of the 10FNIII scaffold of human fibronectin with 17 random residues within the BC and FG loops using mRNA display, an in vitro selection procedure, and an intracellular screen based on colocalization. CaMKII $\alpha$.FingR displayed remarkable specificity, binding to the association domain of CaMKII $\alpha$ at a rate $>20$-fold higher than to CaMKII $\beta$, despite $>76 \%$ identity between the target regions of the two CaMKII isoforms. Localization of CaMKII $\alpha$.FingR-GFP was identical to that of endogenous CaMKII $\alpha$, and the trafficking exhibited by CaMKII $\alpha$.FingR-GFP in spines in response to stimulation by glutamate and glycine was similar to that demonstrated by GFPCaMKII $\alpha$. A crucial advantage of the CaMKII $\alpha$.FingR-GFP over GFP-CaMKII $\alpha$ is that it does not increase the amount of CaMKII $\alpha$ in the cells or induce aberrant clustering.

The effect of $\mathrm{Ca}^{2+}$ on clustering of CaMKII $\alpha$ in the cell body is, paradoxically, the opposite of its effect on clustering in spines. The recruitment of CaMKII $\alpha$ to the actin clusters in the cell body likely occurs through interaction with $\operatorname{CaMKII} \beta$, which has an actin-binding domain that is adjacent to a $\mathrm{Ca}^{2+} /$ calmodulinbinding domain (Shen et al., 1998). Binding of $\mathrm{Ca}^{2+} /$ calmodulin to CaMKII $\beta$ blocks binding of CaMKII $\beta$ to F-actin (O'Leary et al., 2006; Lin and Redmond, 2008), which suggests a mechanism by which influx of $\mathrm{Ca}^{2+}$ could lead to dissociation of CaMKII $\alpha$ from actin. In spines, clustering is mediated by the binding of CaMKII $\alpha$ to the NMDA receptor GluN2B (Bayer et al., 2001, 2006; O'Leary et al., 2011). The fact that the cell body has relatively little GluN2B (Rao et al., 1998) could partially explain the difference between CaMKII $\alpha$ trafficking there and in dendritic spines.

The experiments described in this article raise a number of questions regarding the CaMKII $\alpha$ function. For instance, what is the significance of CaMKII $\alpha$ clusters appearing in $40-45 \%$ of cortical neurons both in vivo and in culture? There was no obvious morphological distinction between neurons with and without CaMKII $\alpha$ clusters, and clusters were found in both excitatory and inhibitory neurons. Although cells containing clusters in cortical sections appeared to be particularly prevalent in layer IV, they were present in all layers. It is also not known what functional significance clustering CaMKII $\alpha$ in the cell body and releasing it following $\mathrm{Ca}^{2+}$ influx might have. CaMKII $\beta$ was shown to associate with spike-like actin protrusions from the cell body of immature (5 DIV) hippocampal neurons (Lin and Redmond, 2008). The appearance of actin "spikes," which surround the perimeter of the cell body and resemble stress fibers found in fibroblasts, suggests that they might be involved in cell adhesion. In contrast, the actin clusters observed in the present article tend to be present in the center of the cell body and, thus, likely do not have functions similar to those of stress fibers.

Another possibility is that the CaMKII $\alpha$ associated with somatic actin platforms might be involved in regulating transcription, as CaMKII has been implicated in transcriptional control in a number of different contexts. Along with $\Delta$ FosB, it participates in a transcriptional feedback loop in the nucleus accumbens shell that is involved in the response to chronic cocaine exposure (Robison et al., 2013). In fact, the chronic addictive behavior can be blocked by even transient expression of a dominant-negative version of CaMKII $\alpha$ (Loweth et al., 2013). CaMKII has also been implicated in activation of CREB in response to electrical activity and $\mathrm{Ca}^{2+}$ influx (Wheeler et al., 2008). In addition, CaMKII phosphorylates the transcription factor neuroD, which stimulates neuronal growth (Gaudillière et al., 2004). In the context of such regulatory mechanisms, it is possible that graded release of CaMKII $\alpha$ from actin platforms in the cell body in response to changes in $\mathrm{Ca}^{2+}$ concentration could modulate transcription in a $\mathrm{Ca}^{2+}$-dependent and activity-dependent fashion.

\section{References}

Andersson AM, Melin L, Bean A, Pettersson RF (1997) A retention signal necessary and sufficient for Golgi localization maps to the cytoplasmic tail of a Bunyaviridae (Uukuniemi virus) membrane glycoprotein. J Virol 71:4717-4727. Medline

Aronowski J, Grotta JC, Waxham MN (1992) Ischemia-induced translocation of $\mathrm{Ca}^{2+} /$ calmodulin-dependent protein kinase II: potential role in neuronal damage. J Neurochem 58:1743-1753. CrossRef Medline

Bayer KU, De Koninck P, Leonard AS, Hell JW, Schulman H (2001) Interaction with the NMDA receptor locks CaMKII in an active conformation. Nature 411:801-805. CrossRef Medline

Bayer KU, LeBel E, McDonald GL, O’Leary H, Schulman H, De Koninck P (2006) Transition from reversible to persistent binding of CaMKII to postsynaptic sites and NR2B. J Neurosci 26:1164-1174. CrossRef Medline

Coultrap SJ, Bayer KU (2012) CaMKII regulation in information processing and storage. Trends Neurosci 35:607-618. CrossRef Medline

Dosemeci A, Reese TS, Petersen J, Tao-Cheng JH (2000) A novel particulate form of $\mathrm{Ca}^{2+} /$ calmodulin-dependent [correction of $\mathrm{Ca}(2+) / \mathrm{CaMKII-}$ dependent] protein kinase II in neurons. J Neurosci 20:3076-3084. Medline

El-Husseini AE, Schnell E, Chetkovich DM, Nicoll RA, Bredt DS (2000) PSD-95 involvement in maturation of excitatory synapses. Science 290: 1364-1368. Medline

Gaudillière B, Konishi Y, de la Iglesia N, Yao GI, Bonni A (2004) A CaMKIIneuroD signaling pathway specifies dendritic morphogenesis. Neuron 41:229-241. CrossRef Medline

Gross GG, Junge JA, Mora RJ, Kwon HB, Olson CA, Takahashi TT, Liman ER, Ellis-Davies GC, McGee AW, Sabatini BL, Roberts RW, Arnold DB (2013) Recombinant probes for visualizing endogenous synaptic proteins in living neurons. Neuron 78:971-985. CrossRef Medline

Hoelz A, Nairn AC, Kuriyan J (2003) Crystal structure of a tetradecameric assembly of the association domain of $\mathrm{Ca} 2+/$ calmodulin-dependent kinase II. Mol Cell 11:1241-1251. CrossRef Medline

Hudmon A, Lebel E, Roy H, Sik A, Schulman H, Waxham MN, De Koninck P (2005) A mechanism for $\mathrm{Ca}^{2+} /$ calmodulin-dependent protein kinase II clustering at synaptic and nonsynaptic sites based on self-association. J Neurosci 25:6971-6983. CrossRef Medline

Koide A, Bailey CW, Huang X, Koide S (1998) The fibronectin type III domain as a scaffold for novel binding proteins. J Mol Biol 284:11411151. CrossRef Medline

Lardi-Studler B, Smolinsky B, Petitjean CM, Koenig F, Sidler C, Meier JC, Fritschy JM, Schwarz G (2007) Vertebrate-specific sequences in the gephyrin E-domain regulate cytosolic aggregation and postsynaptic clustering. J Cell Sci 120:1371-1382. CrossRef Medline

Lewis TL Jr, Mao T, Svoboda K, Arnold DB (2009) Myosin-dependent targeting of transmembrane proteins to neuronal dendrites. Nat Neurosci 12:568-576. CrossRef Medline

Lin YC, Redmond L (2008) CaMKIIbeta binding to stable F-actin in vivo regulates F-actin filament stability. Proc Natl Acad Sci U S A 105:1579115796. CrossRef Medline

Lisman J, Yasuda R, Raghavachari S (2012) Mechanisms of CaMKII action in long-term potentiation. Nat Rev Neurosci 13:169-182. Medline

Liu R, Barrick J, Szostak JW, Roberts RW (2000) Optimized synthesis of RNA-protein fusions for in vitro protein selection. Methods Enzymol 317:268-293. Medline

Loweth JA, Li D, Cortright JJ, Wilke G, Jeyifous O, Neve RL, Bayer KU, Vezina 
P (2013) Persistent reversal of enhanced amphetamine intake by transient CaMKII inhibition. J Neurosci 33:1411-1416. CrossRef Medline

Marsden KC, Shemesh A, Bayer KU, Carroll RC (2010) Selective trans location of $\mathrm{Ca} 2+/$ calmodulin protein kinase IIalpha (CaMKIIalpha) to inhibitory synapses. Proc Natl Acad Sci U S A 107:20559-20564. CrossRef Medline

Marshall J, Molloy R, Moss GW, Howe JR, Hughes TE (1995) The jellyfish green fluorescent protein: a new tool for studying ion channel expression and function. Neuron 14:211-215. CrossRef Medline

O'Leary H, Lasda E, Bayer KU (2006) CaMKIIbeta association with the actin cytoskeleton is regulated by alternative splicing. Mol Biol Cell 17:46564665. CrossRef Medline

O'Leary H, Liu WH, Rorabaugh JM, Coultrap SJ, Bayer KU (2011) Nucleotides and phosphorylation bidirectionally modulate $\mathrm{Ca} 2+/$ calmodulindependent protein kinase II (CaMKII) binding to the N-methyl-D-aspartate (NMDA) receptor subunit GluN2B. J Biol Chem 286:31272-31281. CrossRef Medline

Olson CA, Roberts RW (2007) Design, expression, and stability of a diverse protein library based on the tenth fibronectin type III domain. Protein Sci 16:476-484. CrossRef Medline

Olson CA, Liao HI, Sun R, Roberts RW (2008) mRNA display selection of a high-affinity, modification-specific phospho-IkappaBalpha-binding fibronectin. ACS Chem Biol 3:480-485. CrossRef Medline

Rao A, Kim E, Sheng M, Craig AM (1998) Heterogeneity in the molecular composition of excitatory postsynaptic sites during development of hippocampal neurons in culture. J Neurosci 18:1217-1229. Medline

Roberts RW, Szostak JW (1997) RNA-peptide fusions for the in vitro selection of peptides and proteins. Proc Natl Acad Sci U S A 94:12297-12302. CrossRef Medline

Robison AJ, Vialou V, Mazei-Robison M, Feng J, Kourrich S, Collins M, Wee S, Koob G, Turecki G, Neve R, Thomas M, Nestler EJ (2013) Behavioral and structural responses to chronic cocaine require a feedforward loop involving $\Delta$ FosB and calcium/calmodulin-dependent protein kinase II in the nucleus accumbens shell. J Neurosci 33:4295-4307. CrossRef Medline

Rose J, Jin SX, Craig AM (2009) Heterosynaptic molecular dynamics: locally induced propagating synaptic accumulation of CaM kinase II. Neuron 61:351-358. CrossRef Medline

Rosenberg OS, Deindl S, Comolli LR, Hoelz A, Downing KH, Nairn AC, Kuriyan J (2006) Oligomerization states of the association domain and the holoenyzme of Ca2+/CaM kinase II. Febs J 273:682-694. CrossRef Medline

Sanhueza M, Fernandez-Villalobos G, Stein IS, Kasumova G, Zhang P, Bayer KU, Otmakhov N, Hell JW, Lisman J (2011) Role of the CaMKII/ NMDA receptor complex in the maintenance of synaptic strength. J Neurosci 31:9170-9178. CrossRef Medline

Shakiryanova D, Morimoto T, Zhou C, Chouhan AK, Sigrist SJ, Nose A, Macleod GT, Deitcher DL, Levitan ES (2011) Differential control of presynaptic CaMKII activation and translocation to active zones. J Neurosci 31:9093-9100. CrossRef Medline

Shen K, Meyer T (1999) Dynamic control of CaMKII translocation and localization in hippocampal neurons by NMDA receptor stimulation. Science 284:162-166. CrossRef Medline

Shen K, Teruel MN, Subramanian K, Meyer T (1998) CaMKIIbeta functions as an F-actin targeting module that localizes CaMKIIalpha/beta heterooligomers to dendritic spines. Neuron 21:593-606. CrossRef Medline

Shen K, Teruel MN, Connor JH, Shenolikar S, Meyer T (2000) Molecular memory by reversible translocation of calcium/calmodulin-dependent protein kinase II. Nat Neurosci 3:881-886. CrossRef Medline

Soderling TR (2000) CaM-kinases: modulators of synaptic plasticity. Curr Opin Neurobiol 10:375-380. CrossRef Medline

Takahashi T, Svoboda K, Malinow R (2003) Experience strengthening transmission by driving AMPA receptors into synapses. Science 299: 1585-1588. CrossRef Medline

Vest RS, O'Leary H, Bayer KU (2009) Differential regulation by ATP versus ADP further links CaMKII aggregation to ischemic conditions. FEBS Lett 583:3577-3581. CrossRef Medline

Wheeler DG, Barrett CF, Groth RD, Safa P, Tsien RW (2008) CaMKII locally encodes L-type channel activity to signal to nuclear CREB in excitation-transcription coupling. J Cell Biol 183:849-863. CrossRef Medline 